\title{
Fuzzy Logic and Hybrid based Approaches for the Risk of Heart Disease Detection: State-of-the-Art Review
}

\author{
Jagmohan Kaur $^{1}$ (D) Baljit S. Khehra ${ }^{2}$
}

Received: 10 December 2020/Accepted: 30 May 2021/Published online: 2 August 2021

(C) The Institution of Engineers (India) 2021

\begin{abstract}
Artificial Intelligence, Machine Learning, Fuzzy Logic, Neural Network, Genetic Algorithm and their hybrid systems play vital role in the medical sciences to diagnose various diseases efficiently in the patients. The problems related to the heart are widely comon in today's world. The risk of heart failure develops due to the narrowness and blockage in the coronary arteries of the heart as excess cholesterol deposits in the arteries and blood vessels that results in fatigue, chest pain, dyspnoea, sleeping difficulties and depression. This research aims to explore diverse work done on FL and Hybrid-based techniques to identify the risk of heart disease among the patients. The present study reveals publications along with the strength, operating system, accuracy rate and other specifications used in the identification of heart disease based on FL and Hybrid-based approaches since 2010. This survey contributes motivation for research scholars to generate more innovative ideas and continue their research work in the respective field. Moreover, the future model for direct service of the patients from old age homes to the Intensive Care Unit through ambulance services is also presented in this paper.
\end{abstract}

Keywords Artificial intelligence (AI) .

Machine learning (ML) · Fuzzy logic (FL) .

Neural network $(\mathrm{NN}) \cdot$ Genetic algorithm ·

Intensive care unit (ICU)

Jagmohan Kaur

mohnideep1234@gmail.com

1 IK Gujral Punjab Technical University, Jalandhar, Punjab, India

2 BBSB Engineering College, Fatehgarh Sahib, Punjab, India

\section{Introduction}

The heart disease involves many risks like gender, age, obesity, high blood pressure, high cholesterol, diabetes, family history, drinking alcohol and smoke. Apart from these, there are many other threats like underemployment industrialization, stress due to over work, physical inactivity, depression, stress, diet/routine changes and distressed sleep have increased in this technical and modern world. In addition to this, change in life style, egoism, greed and narcissistic approach of people have triggered the occurrence of chronic diseases in patients.

Heart diseases are categorized into distinct types like congenital heart disease, coronary heart disease (CHD), arrhythmia, dilated cardiomyopathy, heart failure, myocardial infarction (MI), hypertropic cardiomyopathy and mitral regurgitation. The patient having heart problem may feel chest pain, faintness or coolness in arms and legs. However, controlling blood pressure, eating a well-balanced nutritious diet, regulating exercise regime, limited usage of alcohol, tobacco, smoking and gazettes can treat illness and malfunction of the heart.

The mortality rate of the heart patients is the highest in two countries namely: Africa and India, which is $34 \%$ and 23\%, respectively, and it is the lowest in France, Japan and Hong Kong. Both developed and underdeveloped countries have been facing this chronic disease since four decades due to the excess consumption of alcohol, smoking and tobacco. Nowadays, the most of the deaths occur due to coronary heart disease. However, in some European countries, death rate due to heart failure has declined as they are followed by better health/education services and other preventive measures. According to the report of WHO [1], near 17.8 million older and adults face this deadly disease. In fact, the death rate in adults is greater 
than that of the aged people. Centers for Disease Control and Prevention (CDC) [2] have announced that ratio of death rate in Americans is 1:4 that means one out of every four is dead due to heart stroke and 1 out of each 5 people doesn't know that they are affected by silent attack. One more description from British Heart Foundation (BHF) [3] revealed that the panic of pandemic COVID-19 (coronavirus disease) in the year 2020 has become the reason of people dying with heart stroke due to psychological stress and social distancing. All this has even affected the economy of the world as well as of other countries.

With the advancement of power of computer applications can make drastic changes in the medical field by predicting disorder of tumors, lungs, thyroids and heart at very early stage in the patients. Computer-aided heart disease risk diagnose system has many features:
(a) Modern technique
(b) Time saving
(c) Independent from medical experts
(d) Minimize expenditure
(e) Minimal errors
(f) Less human effort
(g) Diminish mortality rate

This era of artificial intelligence comes up with another invention made by the scholars of the Oxford University [4], well known as "fingerprint" a biomarker named as FRP (Fat Radiomic Profile) which is helpful in diagnosing future stroke via scarring and inflammation of blood vessels. The British Heart Foundation (BHF) and the National Institute of Health Research (NIHR) are providing funds for the same.

\section{Research Methodology}

The selection and collection of papers in journals and international conferences have been chosen from state-ofthe-art and well-recognized publishers that ensures the quality of this review paper. Total 53 papers are summarized in this paper, out of which 4 revealed the status of heart disease patients in the world by WHO, BHF, NIHR and $\mathrm{CDC}$ and rest 49 papers bring forward current approaches and algorithms of AI being used for the identification of heart risk since 2010. In the Fig. 1, pie chart shows $73 \%$ of area of publications is covered by hybrid system and $27 \%$ belongs to FL.

Further, references of 21 IEEE, 13 Springer, 9 Elsevier and 4 ACM papers are provided to bring forward the distinct techniques and their combinations being used in heart disease detection along with their data bases, approaches, accuracy and other specifications. Collection of research papers per year and per publication is presented in Figs. 2

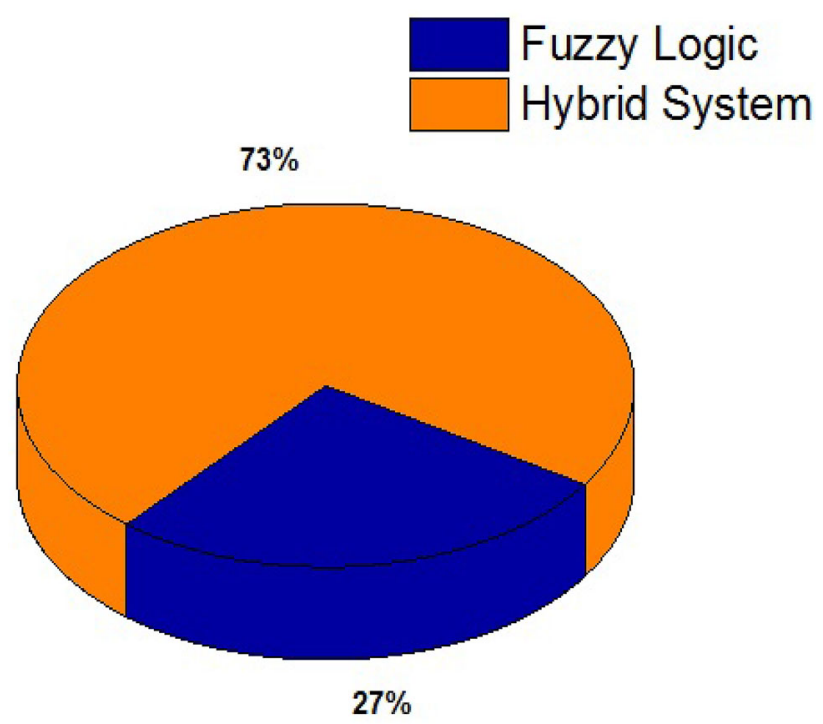

Fig. 1 Publications of fuzzy logic and hybrid system

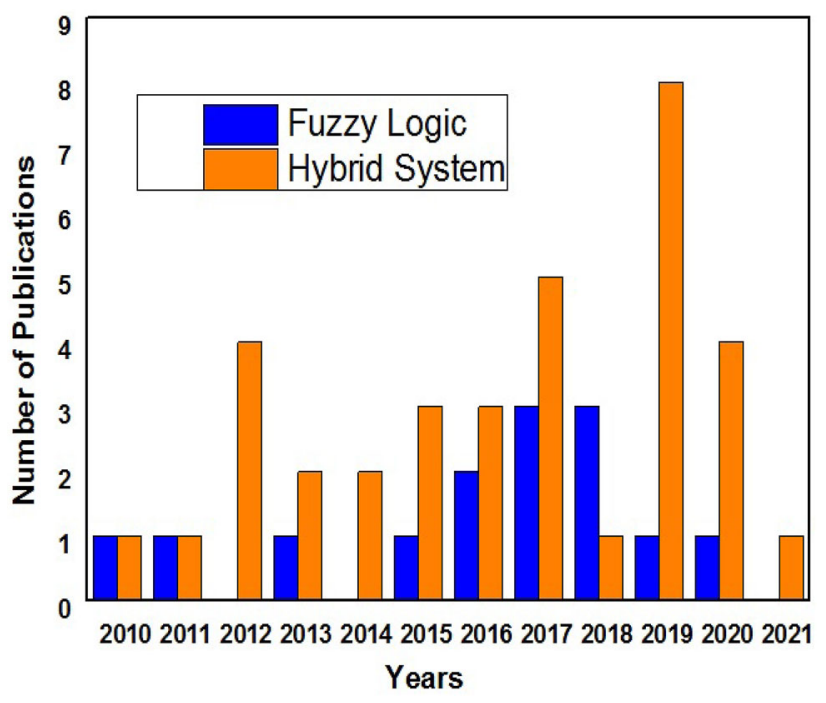

Fig. 2 Collection of research papers per year

and 3, respectively. The Table 1 reveals total number of publications of SCI Index.

\section{Table of Abbreviations of Symptoms and Heart Disease Database}

The following Tables 2 and 3 give the information of abbreviations used for symptoms and heart disease database throughout the paper. 


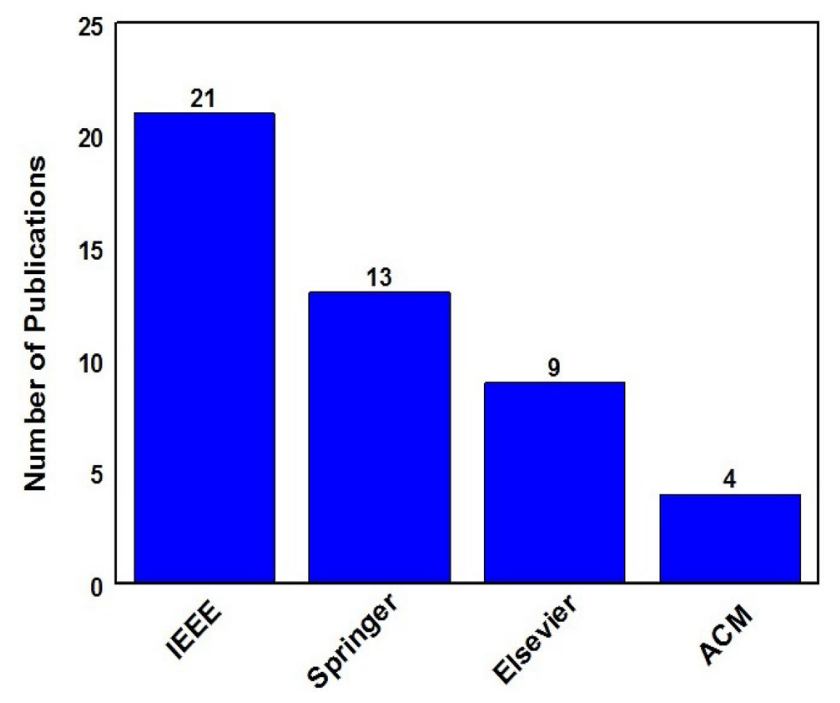

Fig. 3 Collection of research papers per publisher

Table 1 Total no. of publications of SCI index

\begin{tabular}{lll}
\hline Publisher & Research paper & No. of researches \\
\hline IEEE & {$[5-25]$} & 21 \\
Springer & {$[26-38]$} & 13 \\
Elsevier & {$[39-47]$} & 9 \\
ACM & {$[3,48,49,51]$} & 4 \\
\hline
\end{tabular}

\section{Review of FL and Hybrid-Based Approaches for the Risk of Heart Disease Detection}

A mathematical discipline in which the structure of human behavior in the form of uncertainties, true or false forms the basis of FL. FL has following features:
(a) Fascinating area of research
(b) Computational approach
(c) A matter of degrees of truth
(d) A limiting case of estimated reasoning
(e) Performs decision-making with approximate values

The flow chart of algorithm of Fuzzy logic-based approach for the risk of heart disease is shown in the Fig. 4. The combination of two or more than two technologies to find the solution of the peculiar problem, overcome the deficiency of one technique and strengthen the system are known as hybrid systems. In this study, hybridization of techniques has been described as, FL $[8,9,11,12$, $14,15,19,20,25-32,35,36,38-41,45,48,50,52,53]$, GA $[5,7,10,14,18,26,27,36,44]$, Artificial Neural Network (ANN) [5, 7, 10, 13, 35, 42-44, 51], Particle Swarm Optimization (PSO) [13, 33, 41], Ant Colony Optimization (ACO) [37], Naive Bayes (NB) $[16, \quad 18, \quad 23, \quad 29, \quad 34], \quad$ Decision Tree (DT)
$[8,18,20,22,23,28,41,48,51]$, K-means Clustering Algorithm [22], Logistic Regression (LR) [23, 42], Multivariate Adaptive Regression Splines (MARS) [42], Rough Set (RS) [3, 42], Support Vector Machine (SVM) [33, 34], Random Forest (RF) [21, 23], K-Nearest Neighbourhood (K-NN) [18, 30, 37, 46], Logistic Regression SVM (LR SVM) algorithm in [23], has been summarized.

\section{Review of Research Papers from 2010-2013 of FL and Hybrid-Based Approaches}

Adeli et al. [52] demonstrated the fuzzy expert system (2010) using 11 input attributes from database of CCF, LBF and V.A medical Center: AG, CP, CHL, MHR, RBS, RECG, THR, BP, OP, GR, EXANG and 1 output attribute with 5 features: sick (s1-s4) and healthy. Fuzzification was structured in trapezoidal, triangular, $\mathrm{R}$ and $\mathrm{L}$ membership functions. Implementation of Mamdani inference system was made with rule-based system of 44 rules. 'COG' technique was used for defuzzification and yielded $94 \%$ accuracy. Design of the system was implemented in MATLAB. Explanation of hybrid fuzzy-evidential inference engine (2010) was made by Vahib Khatibi et al. [39] using fuzzy sets and Demster-Shafer theory of evidence. The hybrid system achieved $91.58 \%$ accuracy from the data set of patients from V.A medical Center, CCF, HIC and UHS.

An article (2011) by Anooj in [40] revealed the system based on self-received information from the database. Extension in a clinical decision support system was made by using triangular membership functions along with Mamdani fuzzy inference system in programming language MATLAB 7.10. Defuzzification technique ' $C O A$ ' was utilized to achieve $62.35 \%$ of accuracy rate. CCF, V.A medical center and UHS were the main sources of database. E. P. Ephzibah in the paper [26] presented a hybrid system (2011) based on GA and FL in MATLAB 7.3.0 for the smooth work in healthcare field. CCF data set was used for the implementation of the work. Due to GA, 14 selected attributes were reduced to 6 attributes: CP, RBP, EXANG, MHR, OP and CA. Trapezium and triangular membership functions were used in the strategy of fuzzification. Another development in the framework of fuzzy expert system (2012) was initiated by Bhuvaneswari Amma [5] to demonstrate an adaptable disease diagnosis system using hybridization of GA along with NN. It consisted of 13 input variables AG, CP, GR, CHL, RBP, FBS, THS, RECG, MHR, EXANG, OP, CA, SLOPE and 1 output variable for the data base of UIC, Irvine. Accuracy rate was obtained $94.17 \%$ which was evaluated through Root Mean Square Error. The system (2012) described by Ephzibah et al. [27] made use of GA to select salient and 6 prime features responsible for the rapid and error free diagnosis 
Table 2 Table of abbreviations of symptoms

\begin{tabular}{|c|c|c|c|c|}
\hline $\begin{array}{l}\text { Sr. } \\
\text { No }\end{array}$ & Symptoms & Units & Abbreviation & Limit \\
\hline 1 & Age & & AG & $30-86$ \\
\hline 2 & $\begin{array}{l}\text { Chest pain (typical angina, atypical angina, non- anginal pain, } \\
\text { asymptomatic) }\end{array}$ & & $\mathrm{CP}$ & Yes, no \\
\hline 3 & Cholesterol & $\mathrm{mg} \backslash \mathrm{dL}$ & $\mathrm{CHL}$ & $125-200$ \\
\hline 4 & Serum cholesterol & $\mathrm{mg} \backslash \mathrm{dL}$ & Serum CHOL & Less than 200 \\
\hline 5 & Low density lipoprotein & $\mathrm{mg} \backslash \mathrm{dL}$ & LDL CHOL & $18-232$ \\
\hline 6 & High density lipoprotein & $\mathrm{mg} \backslash \mathrm{dL}$ & HDL CHL & $15-111$ \\
\hline 7 & Resting blood pressure $\backslash$ Blood pressure & $\mathrm{mm} \backslash \mathrm{Hg}$ & $\mathrm{RBP} \backslash \mathrm{BP}$ & $75-120$ \\
\hline 8 & Diastolic blood pressure & $\mathrm{mm} \backslash \mathrm{Hg}$ & DBP & 80 -greater than 120 \\
\hline 9 & Systolic blood pressure $\backslash$ High blood pressure & $\mathrm{mm} \backslash \mathrm{Hg}$ & $\mathrm{SBP} \backslash \mathrm{HBP}$ & 130 -greater than 180 \\
\hline 10 & Blood pressure & $\mathrm{mm} \backslash \mathrm{Hg}$ & $\mathrm{BP}$ & 90-190 \\
\hline 11 & Elecrocardiogram $\backslash$ Resting elecrocardiogram & $\mathrm{ms}$ & $\mathrm{ECG} \backslash \mathrm{R}$ ECG & $120-200$ \\
\hline 12 & $\begin{array}{l}\text { Maximum heart rate } \backslash \text { Maximum heart rate achieved during } \\
\text { exercise }\end{array}$ & bpm & MHR $\backslash$ THALACH & Varies \\
\hline 13 & Resting heart rate & bpm & Thal rest & $60-100$ \\
\hline 14 & Gender & & GR & Yes, no \\
\hline 15 & Old peak (ST depression) & & $\mathrm{OP}$ & Variable \\
\hline 16 & Slope of the peak-exercise ST-segment & & SLOPE & Upsloping, flat, downsloping \\
\hline 17 & Blood creatinine level & $\mathrm{mg} \backslash \mathrm{dL}$ & BCL & $0.5-2.2$ \\
\hline 18 & Blood uric acid level & $\mathrm{mg} \backslash \mathrm{dL}$ & BUAL & $\begin{array}{l}2.4-6.0 \text { ( female), } 3.4-7.0 \\
\quad(\text { male })\end{array}$ \\
\hline 19 & Blood sodium level & $\begin{array}{l}.125, .129 \\
.141 \mathrm{mEq} / \mathrm{L}\end{array}$ & BSL & $135-145$ \\
\hline 20 & Height & Feet & HT & \\
\hline 21 & Weight & $\mathrm{Kg}$ & WT & \\
\hline 22 & Pulse rate & ppm & PR & $50-110$ \\
\hline 23 & Fasting blood sugar & $\mathrm{mg} \backslash \mathrm{dL}$ & FBS & $62-400$ \\
\hline 24 & History of hypertension & & HTN & Yes, no \\
\hline 25 & Family history of coronary artery disease & & FAMHIST & Yes, no \\
\hline 26 & History of diabetes & & $\mathrm{DM}$ & Yes, no \\
\hline 27 & Number of major vessels colored by fluoroscopy & & CA & $0-3$ \\
\hline 28 & Exercise-induced Angina & & EXANG & Yes, no \\
\hline 29 & Obesity & & OBES & Yes, no \\
\hline 30 & Thallium scan & & THAL & $\begin{array}{l}\text { Normal, fixed defect, reversible } \\
\text { defect }\end{array}$ \\
\hline
\end{tabular}

of disease and then implemented FL. MATLAB was used as programming language for the data base taken from UCI ML respository. Akhil jabbar et al. [6] revealed the methodology (2012) of association rules which were generated by using hybrid feature subset selection. The paper consisted of mainly 11 input variables: AG, GR, THALACH, LDL CHL, HDL CHL, CHOL, Rural/Urban, BP Systolic, BP Diastolic and Serum Triglycerides. Approach was implemented in the database of Andra Pradesh which yielded $95 \%$ accuracy.
The another system (2012) designed by Muthukaruppan [41] was based on DT and PSO containing 13 input variables: AG, CHOL, BP, GR, THALACH, CP, RECG, OP, EXANG, SLOPE, THAL, CA and 1 output variable. The phenomenon of 'if-then' rule in fuzzy rule-base was applied. The system was designed in MATLAB 7 and yielded accuracy of $93.27 \%$.

The demonstration of another fuzzy expert system (2013) was presented by Sanjeev Kumar et al. [53]. It explained 6 input variables: $\mathrm{CP}, \mathrm{BS}, \mathrm{BP}, \mathrm{CHL}, \mathrm{MHR}, \mathrm{OP}$ and one is decision variable with 5 features. Mamdani 
Table 3 Table of abbreviations of heart disease database

\begin{tabular}{llll}
\hline Sr. No & Heart disease data base & Country & Abbreviation \\
\hline 1 & Cleveland Clinic Foundation & Ohio, US & CCF \\
2 & The Veterans Health Administration & US & V. A. medical center \\
3 & Hungarian Institute of Cardiology & Budepast, Hungary & HIC \\
4 & University of California & Irvine, California & UCI \\
5 & Unified Medical Language System & US & UMLS \\
6 & Massachusetts Institute of Technology, Boston's Beth Israel Hospital & US & MIT-BIH \\
7 & Long Beach Foundation & Long Beach, California & LBF \\
8 & The University Hospital & Zurich, Switerzland & UHS \\
9 & Cleveland Clinic Foundation and Hungarian Institute of Cardiology & US and Hungry & CH \\
\hline
\end{tabular}

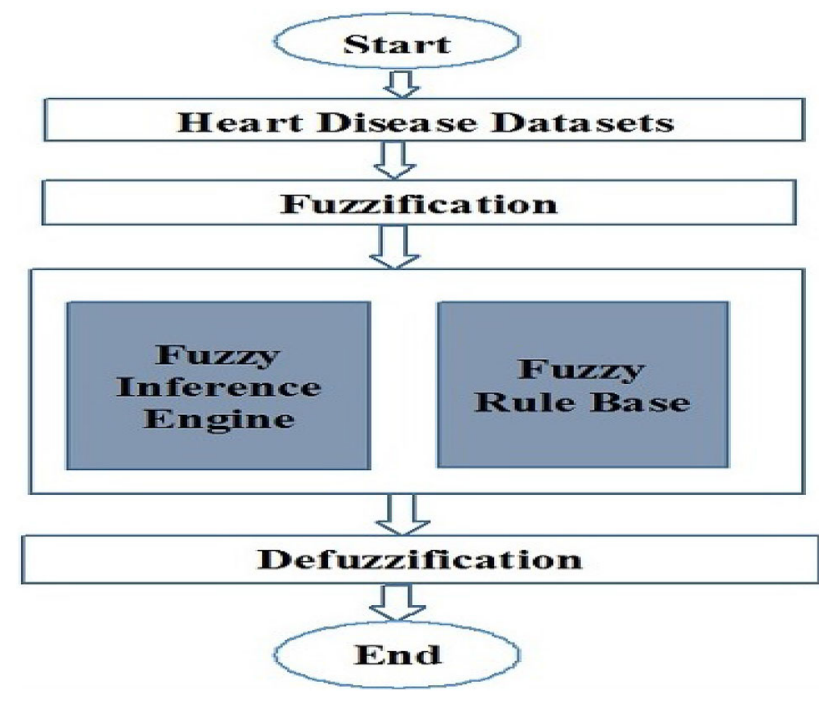

Fig. 4 Flow chart of algorithm of FL-based approach for the risk of heart disease detection

inference system was implemented with rule-based system (22 rules). Rule base was characterized by 'if-then' rules using logical combinations of inputs with AND operator in MATLAB. Center of Gravity (COG) approach was applied for defuzzification, and database was taken from Smt. Parvati Devi hospital, EMC hospital, medical center, Amritsar with accuracy of $92 \%$. The demonstration of another fuzzy expert system (2013) was presented by Syed Umar Amin et al. [7] using a hybrid system of ANN along with GA for prediction of heart disease. Total 12 input variables: GR, AG, CHL, BP, FAMHIST, SMOKE, alcohol intake, physical activity, DM, diet, OBES, stress and 1 output variable were used. The article used input (12), hidden (10) and output (2) nodes, respectively. Implementation was done in MATLAB R2012a. Accuracy of 92\% was measured by applying least mean square error (MSE). Jae-Kwon Kim et al. [28] represented prediction model (2013) of heart disease in MATLAB to overcome the uncertainty received from the medical experts by using FL and GA with an accuracy of $69.22 \%$. The fuzzy rule base generated 'if-then' rules by making use of C4.5 algorithm of the DT. Experiment was conducted on 299 patients of Gill medical center, Korea by taking 7 input variables GR, AG, CHL, HDL CHL, RBP, DM and SMOKE. The Table 4 presents the list of research papers from 2010-2013 of FL and Hybrid-based approaches.

\section{Review of Research Papers from 2014-2017 of FL and Hybrid-Based Approaches}

Explanation of hybrid model (2014) was made by Yuehjen E. Shao et al. [42] consisted of many hybrid approaches MARS, LR, RS and ANN techniques. Input variables: AG, CP, GR, RBP, FBS, Serum CHOL, RECG, EXANG, THALACH, OP, CA, THAL were used in this hybrid model and attained $83.93 \%$ accuracy evaluated by Root Mean Square Error in RESE software. Jan Bohacik et al. [8] applied cumulative application of FL Controller and DT in heart disease diagnosis (2014). Coding was developed in weka tool with a data base from Hull York medical school and University of Hull, England with sensitivity and specificity $34.23 \%$ and $91.01 \%$ respectively.

Again Jan Bohacik et al. [9] developed an Algorithmic Model (2015) for heart disease patients by employing the same on 2032 patients of Hull York medical school and University of Hull, England with an accurate rate $64.41 \%$ and specificity $63.27 \%$. The system considered 9 input variables: BCL, BUAL, GR, BSL, AG, WT, PR, HT and NT-proBNPlevel. Software tool Java was implemented in fuzzy inference system. The hybrid technique (2015) designed by Ankita Dewan [10] evolved a prototype to find and execute unknown information from the database of heart disease. Genetic Algorithm was hybrid with back propagation method. The study used 20,10 and 10 as input, hidden and output nodes, respectively. MATLAB R2012a was used for the implementation of the task. The proposed 
methodology achieved nearly $100 \%$ with least error but being stiffen in local minima, the system was unable to achieve the desired outcome. The focus of Hui Yang et al. [29] was to construct a hybrid model (2015) for the heart failure identification by combining FL and NB in MALLET operating system. The system made use of 7 main risk factors responsible for heart stroke extracted from UMLS database and yielded $91.5 \%$ accuracy with precision 88.4\%. Krishnaiah et al. [30] developed a robust system (2015) using data mining techniques: FL Controller and K-NN algorithm with a capability of reducing uncertainty available in the medical data. Weka 3.6.6 was used in the system which got $91 \%$ accuracy. Mainly 13 input attributes : AG, CR, CP, RBP, CHOL, RECG, FBS, THALACH, EXANG, OP, SLOPE,CA, THAL were considered and testing was conducted on 550 patients of heart disease databases of CCF and Statlog.

The design of fuzzy expert engine (2016) was developed by Wiga Maulana et al. [11]. The system made use of 13 input variable: $\mathrm{AG}, \mathrm{CP}, \mathrm{CHL}, \mathrm{MNR}$, RBS, RECG, THAL, BP, OP, GR, EXANG, SLOPE, CA and 1 output variable: the status of angiography. The system used C4.5, CART and RIPPER in MATLAB (7.12 R2011a). The membership functions were optimized by imperialist competitive algorithm (ICA). The designed method was experimented on data sets from CCF and HIC, Budapest with an accuracy of $81.82 \%$. Assemgul Duisenbayeva et al. [12] revealed more adaptable and compatible fuzzy inference system (2016) that assist doctors and physicians in their decision-making for CAD disease. CP, BP, LDL CHL, BS, GR, MHR and AG were 7 input and 1 output variable having 5 features: sick (s1-s4), healthy. The given approach was implemented in MATLAB. Coronary heart disease prediction system (2016) was developed by Mokeddem et al. [48] hybrid with SIPINA Decision Tree algorithm and Fuzzy logic. The system used 13 input features from the wellknown CCF, HIC, LBF and UCI heart disease data sets using triangular, trapezoidal, $\mathrm{R}$ and $\mathrm{L}$ membership functions. 'if-then' rules were used in rule-base using logical combinations of inputs with AND operator. Centroid method was used for defuzzification. This new approach has yielded an accuracy of $94.05 \%$. Feshki et al. [13] proposed the system of diagnosis (2016) that yielded results in less time and cost with an accuracy of $91.94 \%$. AG, CP, RBP upon admission in hospital, GR, CHL, FBS, CA, RECG results, EXANG, MHR, OP, SLOPE and thalassemia were 13 attributes considered in this paper. The Particle Swarm Optimization was implemented to extract 8 features. Further, Feed Forward Back-Propagation Neural network (FFBPNN) was applied to optimize the PSO algorithm. Cleveland Clinic Foundation (CCF) data set was used. Fuzzy Decision Support System (2016) to predict heart disease was applied by Animesh Kumar Paul et al.
[14] to pre-process data set, select effective attributes and then to make a strategy of fuzzy rule base. Accuracy of this approach is very close to near $80 \%$. CCF, HIC, UHS and V. A. medical center heart disease datasets from the UCI ML repository were used in this system. $\mathrm{C}++$ was used to implement the system.

An overview of fuzzy logic controller (2017) for coronary heart disease with 9 input variables: AG, CHL, BS, CP, ECG, HR,EX, GR, SMOKE and 1 output variable with 5 features was proposed by Mohammad Alqudah [31]. Trapezoidal, triangular, $\mathrm{R}$, and $\mathrm{L}$ membership functions were used for all variables. Mamdani inference system with rule-based system (66 rules) using logical combinations of inputs with 'AND' operator was implemented on patients' records in Jordan'. Coding was done in Visual Studio 2010 $\mathrm{C}$ which accomplished the diagnosis by yielding high accuracy. Tanmey Kasbe et al. [15] designed fuzzy expert system (2017) with 10 input variables: CP, CHOL, SBP, FBS, MHR, ECG, THAL, OP, AG, GR and 1 output variable with 5 parameters. Mamdani inference mechanism was implemented with rule-based system (86 rules) characterized by 'if-then' rules using logical combinations of attributes with AND/OR operator. Fuzzification was accomplished using triangular and trapezoidal membership function. MATLAB R2008 tool was used as programming language and Center of Gravity (COG) approach was applied for defuzzification and finally achieved $93.33 \%$ accuracy. V.A medical center, CCF and LBF were data set sources. Coronary illness framework (2017) was applied by Purushottam Sharma et al. [32] considered 13 input attributes: AG, GR, CP, FBS, RBP, RECG, THALACH, EXANG, OP, SLOPE, CA, THAL and CHOL from the data set of Hungary, Switzerland and U.S. The paper made use of very common combination of FL and GA, and brought $88.11 \%$ accuracy. Creation of accurate rule set was the main theme of this article. With a purpose of improvement in accuracy and reduction in computational time Kanika Pahwa and Ravinder Kumar [16] proposed prediction method of heart disease (2017) by hybridization of techniques NB and RF. Both these techniques yielded $84.15 \%$ and $84.16 \%$ accuracy, respectively. Kaan Uyar et al. [43] presented diagnosis of heart disease model (2017) using 13 input attributes: AG, GR, CP, RBP, CHOL, FBS, RECG, THALACH, EXANG, OP, SLOPE, CA and THAL. GA-based Recurrent Fuzzy Neural Network (RFNN) involved 13 input, 7 hidden and 1 output neurons. An accuracy of $97.78 \%$ was yielded by experimentation on CCF patients' data set which was further evaluated by RMSE (Root Mean Square Error). Programming Languages Ubuntu and Java were used for the implementation of the system. Utilization of hybrid data mining techniques (2017) was demonstrated by Meenal Saini et al. [17] using 13 attributes AG, GR, CP, RBP, 
Table 4 List of research papers from 2010-2013 of FL and Hybrid-based approaches

\begin{tabular}{|c|c|c|c|c|c|}
\hline $\begin{array}{l}\text { Year } \\
\text { and } \\
\text { paper }\end{array}$ & Author & Title & $\begin{array}{l}\text { Application } \\
\text { Software }\end{array}$ & AI approach & Strength \\
\hline $\begin{array}{l}2010 \\
{[52]}\end{array}$ & Ali Adeli, Mehndi Neshant & $\begin{array}{l}\text { A Fuzzy Expert System for } \\
\text { Heart Disease Diagnosis }\end{array}$ & MATLAB & FL & $\begin{array}{l}\text { Simulation of the expert and doctor } \\
\text { with presentation of definite output } \\
\text { in an undefinate term }\end{array}$ \\
\hline $\begin{array}{l}2010 \\
{[39]}\end{array}$ & $\begin{array}{l}\text { Vahib Khatibi, Gholam Ali } \\
\text { Montazerac }\end{array}$ & $\begin{array}{l}\text { A Fuzzy -Evidential Hybrid } \\
\text { Inference Engine for } \\
\text { Coronary Heart Disease Risk } \\
\text { Assessment }\end{array}$ & - & $\begin{array}{l}\text { Demster-Shafer } \\
\text { theory of } \\
\text { evidence and } \\
\text { fuzzy sets } \\
\text { theory (DFT) }\end{array}$ & $\begin{array}{l}\text { Requisite of a precise, certain and firm } \\
\text { decision-making to formulate a } \\
\text { model in various problems of } \\
\text { engineering }\end{array}$ \\
\hline $\begin{array}{l}2011 \\
{[40]}\end{array}$ & P. K. Anooj & $\begin{array}{l}\text { Clinical Decision Support } \\
\text { System: Risk Level } \\
\text { Prediction of Heart Disease } \\
\text { using Weighted Fuzzy Rules }\end{array}$ & $\begin{array}{l}\text { MATLAB } \\
\quad(7.10)\end{array}$ & FL & $\begin{array}{l}\text { Development of a medical decision } \\
\text { support system based on fuzzy rule } \\
\text { engine in order to classify training } \\
\text { and testing database depending on } \\
\text { risk level }\end{array}$ \\
\hline $\begin{array}{l}2011 \\
{[26]}\end{array}$ & E. P. Ephzibah & $\begin{array}{l}\text { A Hybrid Genetic-Fuzzy } \\
\text { Expert System for Effective } \\
\text { Heart Disease Diagnosis }\end{array}$ & $\begin{array}{l}\text { MATLAB } \\
7.3 .0\end{array}$ & FL and GA & $\begin{array}{l}\text { Implementation of the diagnosis model } \\
\text { dependant upon knowledge-based } \\
\text { expert system for the smooth work in } \\
\text { the healthcare industries }\end{array}$ \\
\hline $\begin{array}{r}2012 \\
{[5]}\end{array}$ & Bhuvaneswari Amma NG & $\begin{array}{l}\text { Cardiovasular Disease } \\
\text { Prediction System using } \\
\text { Genetic Algorithm and } \\
\text { Neural Network }\end{array}$ & - & GA and NN & $\begin{array}{l}\text { Analysis of nonlinear functions and } \\
\text { attribute selection to construct a } \\
\text { compatible model }\end{array}$ \\
\hline $\begin{array}{l}2012 \\
{[27]}\end{array}$ & $\begin{array}{l}\text { E. P. Ephzibah, V. } \\
\text { Sundrapandian }\end{array}$ & $\begin{array}{l}\text { A Fuzzy Rule Based Expert } \\
\text { System for Effective Heart } \\
\text { Disease Diagnosis }\end{array}$ & MATLAB & FL and GA & $\begin{array}{l}\text { Selection of the salient and prime } \\
\text { features responsible for the rapid and } \\
\text { error free diagnosis of disease }\end{array}$ \\
\hline $\begin{array}{r}2012 \\
{[6]}\end{array}$ & $\begin{array}{l}\text { M. Akhil jabbar, Priti } \\
\text { Chandra, B. } \\
\text { L. Deekshatulu }\end{array}$ & $\begin{array}{l}\text { Prediction of risk score for } \\
\text { heart disease using } \\
\text { associative classification and } \\
\text { hybrid feature subset } \\
\text { selection }\end{array}$ & WEKA & $\begin{array}{l}\text { Association rules } \\
\text { generated by } \\
\text { hybrid feature } \\
\text { subset } \\
\text { selection }\end{array}$ & $\begin{array}{l}\text { Associative classification rules and } \\
\text { feature subset selection. Discovery of } \\
\text { a new rule set through extraction of } \\
\text { important information from } \\
\text { knowledgeable data base of UCI to } \\
\text { detect risk score in Andhra Pradesh }\end{array}$ \\
\hline $\begin{array}{l}2012 \\
{[41]}\end{array}$ & S. Muthukaruppan, M. J. Er & $\begin{array}{l}\text { A Hybrid Particle Swarm } \\
\text { Optimization Based Fuzzy } \\
\text { Expert System for the } \\
\text { Diagnosis of Coronary Heart } \\
\text { Disease }\end{array}$ & MATLAB 7 & $\begin{array}{l}\text { Fuzzy Expert } \\
\text { System, DT } \\
\text { and PSO }\end{array}$ & $\begin{array}{l}\text { Potentiality in the interpretation of the } \\
\text { judgement through fuzzy expert } \\
\text { engine based on PSO }\end{array}$ \\
\hline $\begin{array}{l}2013 \\
{[53]}\end{array}$ & $\begin{array}{l}\text { Sanjeev Kumar, } \\
\text { Gursimranjeet Kaur }\end{array}$ & $\begin{array}{l}\text { Detection of Heart Disease } \\
\text { using Fuzzy Logic }\end{array}$ & MATLAB & $\begin{array}{l}\text { Fuzzy expert } \\
\text { system }\end{array}$ & $\begin{array}{l}\text { Itself usage by the patients and less } \\
\text { scope of redundancy and conflicts in } \\
\text { the generation of fuzzy rules }\end{array}$ \\
\hline $\begin{array}{r}2013 \\
{[7]}\end{array}$ & $\begin{array}{l}\text { S. U. Amin, K. Agarwal } \\
\text { and R. Beg }\end{array}$ & $\begin{array}{l}\text { Genetic Neural Network based } \\
\text { Data Mining in Prediction of } \\
\text { Heart Disease using Risk } \\
\text { Factors }\end{array}$ & $\begin{array}{r}\text { MATLAB } \\
\text { R2012a }\end{array}$ & GA and NN & $\begin{array}{l}\text { Insurance of early prediction of the } \\
\text { disease and hence insurance of } \\
\text { reduction in the expenditure during } \\
\text { clinical tests and treatments of the } \\
\text { disease }\end{array}$ \\
\hline $\begin{array}{l}2013 \\
{[28]}\end{array}$ & $\begin{array}{l}\text { Jae-Kwon Kim, Jong-Sik } \\
\text { Lee, Dong-Kyun Park, } \\
\text { Yong-Soo Lim, Young- } \\
\text { Ho Lee, Eun-Young } \\
\text { Jung }\end{array}$ & $\begin{array}{l}\text { Adaptive mining prediction } \\
\text { model for content } \\
\text { recommendation to coronary } \\
\text { heart disease patients }\end{array}$ & MATLAB & $\begin{array}{l}\text { FL Controller and } \\
\text { DT }\end{array}$ & $\begin{array}{l}\text { Importance of linking medical expert } \\
\text { knowledge and information with data } \\
\text { mining approaches and reducing } \\
\text { uncertainty in the prediction } \\
\text { framework using information and } \\
\text { knowledge from medical resource } \\
\text { persons }\end{array}$ \\
\hline
\end{tabular}

CHOL, FBS, RECG, CA, THAL, EXANG, THALACH, OP and SLOPE. This approach has considered hybridization of 9 classifiers classifiers: SVM, Decision tree, Neural
Network, Bayesian regularized NN, Generalized linear model, Lasso, MARS, Classification and Regression Tree and come out with an accuracy of $82.54 \%$. Arabasadi et al. 
[44] presented an adaptive and affordable technique (2017) for the enhancement of accuracy and finally achieved $93.85 \%$. The system combined together GA and NN, and involved 22 input, 5 hidden and 1 output neurons. Experimentations were done on 303 patients with data set from HIC, CCF and LBF. The identification of heart disease diagnosis (2017) was derived by Abhishek Rairikar et al. [18] using hybridization of GA, DT and KNN. The use of 13 vital clinical attributes was considered to achieve considerable accuracy rate. The Table 5 presents the list of research papers from 2014-2017 of FL and Hybrid-based approaches.

\section{Review of Research Papers from 2018-2020 of FL and Hybridbased Approaches}

Explanation of a mediative fuzzy logic system (2018) given by Ion Iancu [45] has considered 11 input variables: CP, CHL, BP, MHR, BS, RECG, EX, THAL, OP, AG, GR and 1 output variable with 5 features. Mamdani inference system was implemented with rule-based system (44 rules) using 'single input-single output' phenomenon. Software MATLAB was used for the implementation of experimental work from the data base of CCF, V. H. medical center and LBF. Defuzzification was done using 'Middle of maxima and middle of minima' approach. Hasan Kahtan et al. [49] proposed a FL system with 4 inputs variables: AG, BS, BP and CHL. Fuzzification was done using trapezoidal membership function for all variables. A rulebased system (96) was implemented in JAVA (using Net Beans IDE 8.2 in Java) with an accuracy of $98 \%$. The Fuzzy Inference System (2018) designed by Vishu Madaan et al. [19] has resolved a peculiar problem of diagnosis by making use of 6 input parameters: AG, BP, CP, CHL, HR and DM. The rule base set contained 162 rules (if-then rule) with the implementation in MATLAB tool. The proposed model has acquired $82.65 \%$ accuracy. Another hybrid system (2018) based on FL controller and DT was described by Oumaima Terrada et al. [20] using 14 clinical input parameters: Total CHL, HDL, LDL, HBP, SMOKE, OBES, DM, GR, BMI, SBP, TRIG, AG, FAMHIS and sedentary lifestyle. Software MATLAB was used the experiments of diagnosis for the rule base consisting of logical combinations of AND operator and gave $63.24 \%$ accuracy.

The study developed by Prerna Jain et al. [50], displayed the system (2019) considering 8 input variables: AG, CHL, GR, OBY, HTN, DM, FAMHIS, SMOKE and 1 output variable with 3 parameters. Fuzzification was done using triangular and trapezoidal membership functions for each and every all input variable. Mamdani approach was used in rule base system (44 rules) using if-else statements. The system was designed in programming language MATLAB and achieved $91 \%$ of accuracy. J. Vijayashree et al. [33] presented ML framework (2019) using 11 input attributes: AG, GR, CP, RBP, FBS, CHOL, CA, OP, RECG, SLOPE and THALACH. Hybridization of PSO-SVM was utilized and compared with other classifiers and using the data base of staLog heart disease set and yielded $88.22 \%$ accuracy results and implementation was done in MATLAB. The Hybrid system (2019) was expanded by M. Tarawnah et al. [34] for heart disease identification. The system comprised of 11 input variables from the data base of CCF and UCI $\mathrm{ML}$ respository. Implementation of classification techniques NB, SVM, J4.8, NN, GA and RF was shown and compared with the hybrid approach of all techniques. Accuracy obtained was $89.2 \%$ and it was achieved by hybrid approach which was better than all other approaches. Senthil kumar Mohan et al. [21] used hybrid ML techniques (RF and Linear Model (HRFLM)) to demonstrate an effective heart disease prediction framework (2019) with an accuracy of $88.7 \%$. The study made use of 13 attributes: AG, GR, CP, RBP, CHOL, FBS, RECG, OP, SLOPE, CA, THAL, MHR and EXANG. Classification of heart disease was done in $\mathrm{R}$ Studio Rattle software tool using the data of 297 patients obtained from CCF data set. Heart disease detection hybrid classifier (2019) was represented by Yukti Sharma [22] using hybridization of DT and K-Means Clustering. The study considered 14 attributes namely: AG, GR, CP, BP, CHL level, BS, ECG, THAL, CA and SLOPE obtained from CCF data base. Classifier K-Means Clustering and Decision Tree obtained $49 \%$ and $52 \%$ accuracy, respectively, and the proposed work of hybrid classifier yielded $62 \%$ accuracy which was greater than that of individual classifiers. Saba Bashir et al. [23] gave an emphasis on approaches and algorithms of attribute selection in datasets of heart disease diagnosis system (2019) using 4 classifiers. Logistic Regression SVM yielded $84.85 \%$ accuracy which is the highest among the accuracies obtained using DT (82.22\%), LR (82.56\%), RF $(84.17 \%)$ and NB (84.24\%) algorithms on UCI database in Rapid Miner Studio software tool. Presentation of a fuzzybased framework (2019) was proposed by Padmavathi Kora et al. [46] for valvular heart disease detection by considering 7 clinical input variables: AG, BP, CHL, DM, BMI, SMOKE and physical activity with 1 output variable having 3 features. After training the dataset using NN, Mamdani inference framework was implemented with rule set system (44 rules) 'if-then' rules using logical combinations of inputs with AND operator. The source of dataset was CCF and HIC. Parameter ROC Curve (Receiver Operator Characterstic) was used to check the accuracy of 99.3\% in MATLAB R2019b. The another proposal (2019) using Imperialist Competitive Algorithm (ICA) to select optimal features and K-nearest neighbor approach (KNN) was used to classify heart disease by J. Nourmohammad- 
Table 5 List of research papers from 2014-2017 of FL and Hybrid-based approaches

\begin{tabular}{|c|c|c|c|c|c|}
\hline $\begin{array}{l}\text { Year } \\
\text { and } \\
\text { paper }\end{array}$ & Author & Title & $\begin{array}{l}\text { Application } \\
\text { software }\end{array}$ & AI approach & Strength \\
\hline $\begin{array}{l}2014 \\
{[42]}\end{array}$ & $\begin{array}{l}\text { Yuehjen E. Shaoa, Chia- } \\
\text { Ding Houa, and Chih- } \\
\text { Chou Chiu }\end{array}$ & $\begin{array}{l}\text { Hybrid Intelligent Modeling } \\
\text { Schemes for Heart Disease } \\
\text { Classification }\end{array}$ & $\begin{array}{l}\text { RESE } \\
\text { software }\end{array}$ & $\begin{array}{l}\text { LR, MARS, } \\
\text { RS and NN } \\
\text { techniques }\end{array}$ & $\begin{array}{l}\text { Enlargement of a hybrid model using } \\
\text { least input variables and having distinct } \\
\text { classification capability }\end{array}$ \\
\hline $\begin{array}{r}2014 \\
{[8]}\end{array}$ & $\begin{array}{l}\text { Jan Bohacik, C. } \\
\text { Kambhampati, Darryl } \\
\text { N. Davis, J. G. F. } \\
\text { Clevland }\end{array}$ & $\begin{array}{l}\text { Use of Cumulative Information } \\
\text { Estimations for Risk } \\
\text { Assessment of Heart Failure } \\
\text { Patients }\end{array}$ & Weka & $\begin{array}{l}\text { FL Controller } \\
\text { and DT }\end{array}$ & $\begin{array}{l}\text { An algorithmic as well as intelligent } \\
\text { home tele-monitoring model based on } \\
\text { cumulative system of Fuzzy Logic and } \\
\text { Decision Tree }\end{array}$ \\
\hline $\begin{array}{r}2015 \\
{[9]}\end{array}$ & $\begin{array}{l}\text { J. Bohacik, K. Matiasko, } \\
\text { M. Benedikovic, I. } \\
\text { Nedeljakova }\end{array}$ & $\begin{array}{l}\text { Algorithmic Model for Risk } \\
\text { Assessment of Heart Failure } \\
\text { Patients }\end{array}$ & Java & $\begin{array}{l}\text { Fuzzy Expert } \\
\text { System }\end{array}$ & $\begin{array}{l}\text { Challenged a task by using AI or } \\
\text { computer aided technology to develop } \\
\text { an effective and intelligent biomedical } \\
\text { diagnosis system }\end{array}$ \\
\hline $\begin{array}{l}2015 \\
{[10]}\end{array}$ & $\begin{array}{l}\text { Ankita Dewan and } \\
\text { Meghna Sharma }\end{array}$ & $\begin{array}{l}\text { Prediction of Heart Disease } \\
\text { using a Hybrid Technique in } \\
\text { Data Mining Classification }\end{array}$ & $\begin{array}{r}\text { MATLAB } \\
\text { R2012a }\end{array}$ & $\begin{array}{l}\text { NN with back } \\
\text { propagation } \\
\text { method and } \\
\text { GA }\end{array}$ & $\begin{array}{l}\text { A promising, feasible, supportive and } \\
\text { suitable system concluding smart } \\
\text { medical decisions }\end{array}$ \\
\hline $\begin{array}{l}2015 \\
{[29]}\end{array}$ & $\begin{array}{l}\text { Hui Yang and Jonathan } \\
\text { Garibaldi }\end{array}$ & $\begin{array}{l}\text { A Hybrid Model for Automatic } \\
\text { Identification of Risk factors } \\
\text { for Heart Disease }\end{array}$ & MALLET & $\begin{array}{l}\text { Rule -based } \\
\text { methods and } \\
\text { NB }\end{array}$ & $\begin{array}{l}\text { A robust knowledge extraction system } \\
\text { with less human effort for automatic } \\
\text { detection of heart disease }\end{array}$ \\
\hline $\begin{array}{l}2015 \\
{[30]}\end{array}$ & $\begin{array}{l}\text { V. Krishnaiah, G. } \\
\text { Narsimha and N. } \\
\text { Subhash Chandra }\end{array}$ & $\begin{array}{l}\text { Heart Disease Prediction System } \\
\text { Using Data Mining technique } \\
\text { for Fuzzy K-NN Approach }\end{array}$ & Weka 3.6.6 & $\begin{array}{l}\text { FL Controller } \\
\text { and K-NN } \\
\text { algorithm }\end{array}$ & $\begin{array}{l}\text { Capability to eliminate uncertainty } \\
\text { available in the medical data using data } \\
\text { mining techniques }\end{array}$ \\
\hline $\begin{array}{l}2016 \\
{[11]}\end{array}$ & $\begin{array}{l}\text { Wiga Maulana Baihaqi, } \\
\text { Noor Akhmad Setiawan } \\
\text { and Igi Ardiyanto }\end{array}$ & $\begin{array}{l}\text { Rule Extraction for Fuzzy } \\
\text { Expert System to Diagnose } \\
\text { Coronary Artery Disease }\end{array}$ & $\begin{array}{l}\text { MATLAB } \\
\quad 7.12 \\
\text { (R2011a) }\end{array}$ & FL contoller & $\begin{array}{l}\text { Development of a new prototype along } \\
\text { with the comparison of performance } \\
\text { with other models and classification of } \\
\text { overall error rate of the data }\end{array}$ \\
\hline $\begin{array}{l}2016 \\
{[12]}\end{array}$ & $\begin{array}{l}\text { Assemgul Duisenbayeva, } \\
\text { Lyazzat Atymtayeva, } \\
\text { Iskander Beisembetov }\end{array}$ & $\begin{array}{l}\text { Using Fuzzy logic concepts in } \\
\text { creating the decision making } \\
\text { expert system for cardio- } \\
\text { vascular diseases (CVD) }\end{array}$ & MATLAB & $\begin{array}{l}\text { Fuzzy } \\
\quad \text { inference } \\
\text { system }\end{array}$ & $\begin{array}{l}\text { Assistance to the physicians and } \\
\text { practitioners by taking decisions, } \\
\text { reducing time period to determine } \\
\text { disease and producing error-free results }\end{array}$ \\
\hline $\begin{array}{l}2016 \\
{[48]}\end{array}$ & $\begin{array}{l}\text { Sidahmed Mokeddem and } \\
\text { Baghdad Atmani }\end{array}$ & $\begin{array}{l}\text { Assessment of Clinical Decision } \\
\text { Support Systems for } \\
\text { Predicting Coronary Heart } \\
\text { Disease }\end{array}$ & - & $\begin{array}{l}\text { FL and } \\
\text { SIPINA DT }\end{array}$ & $\begin{array}{l}\text { Necessity of the application of attribute } \\
\text { selection technique for the removal of } \\
\text { the irrelevant and redundant factors } \\
\text { available in the database of heart } \\
\text { disease }\end{array}$ \\
\hline $\begin{array}{l}2016 \\
{[13]}\end{array}$ & $\begin{array}{l}\text { M. G. Feshhki and O. } \\
\text { S. Shijani }\end{array}$ & $\begin{array}{l}\text { Improving the Heart Disease } \\
\text { Diagnosis by Evolutionary } \\
\text { Algorithm of PSO and Feed } \\
\text { Forward NN }\end{array}$ & - & $\begin{array}{l}\text { NN Feed } \\
\text { Forward } \\
\text { Back } \\
\text { Propagation } \\
\text { and PSO }\end{array}$ & $\begin{array}{l}\text { Utilization of artificial intelligence and } \\
\text { mining of data to extract cognizant } \\
\text { output to mark the improvement in the } \\
\text { framework }\end{array}$ \\
\hline $\begin{array}{l}2016 \\
{[14]}\end{array}$ & $\begin{array}{l}\text { Animesh Kumar Paul, } \\
\text { Pintu Chandra Shill, } \\
\text { Md. Rafiqul Islam Rabin } \\
\text { and M. A. H. Akhand }\end{array}$ & $\begin{array}{l}\text { Genetic Algorithms Based } \\
\text { Fuzzy Decision Support } \\
\text { System for the Diagnosis of } \\
\text { Heart Disease }\end{array}$ & $\mathrm{C}++$ & $\begin{array}{l}\text { Fuzzy } \\
\text { Decision } \\
\text { Support } \\
\text { System } \\
\text { (FDSS) and } \\
\text { GA }\end{array}$ & $\begin{array}{l}\text { Consumption of only relevant and } \\
\text { irredundant features to achieve } \\
\text { admissible exactness from the } \\
\text { generalization of FDSS }\end{array}$ \\
\hline $\begin{array}{l}2017 \\
{[31]}\end{array}$ & Ali Mohammad Alqudah & $\begin{array}{l}\text { Fuzzy Expert System for } \\
\text { Coronary Heart Disease } \\
\text { Diagnosis in Jordan }\end{array}$ & $\begin{array}{l}\text { Visual } \\
\text { Studio } \\
2010\end{array}$ & $\begin{array}{l}\text { Fuzzy Logic } \\
\text { Contoller }\end{array}$ & $\begin{array}{l}\text { Demonstration of the method which is } \\
\text { easily applicable on the patients' } \\
\text { clinical data and construct a mobile- } \\
\text { based web or application for e-health } \\
\text { support system }\end{array}$ \\
\hline $\begin{array}{l}2017 \\
{[15]}\end{array}$ & $\begin{array}{l}\text { Tanmay Kasbe and Ravi } \\
\text { Singh Pippal }\end{array}$ & $\begin{array}{l}\text { Design of Heart Disease } \\
\text { Diagnosis System using } \\
\text { Fuzzy Logic }\end{array}$ & MATLAB & $\begin{array}{l}\text { Fuzzy Logic } \\
\text { Controller }\end{array}$ & $\begin{array}{l}\text { A competent, reasoning and powerful } \\
\text { approach in order to manage variability } \\
\text { of the available data }\end{array}$ \\
\hline
\end{tabular}


Table 5 continued

\begin{tabular}{|c|c|c|c|c|c|}
\hline $\begin{array}{l}\text { Year } \\
\text { and } \\
\text { paper }\end{array}$ & Author & Title & $\begin{array}{l}\text { Application } \\
\text { software }\end{array}$ & AI approach & Strength \\
\hline $\begin{array}{l}2017 \\
{[32]}\end{array}$ & $\begin{array}{l}\text { Purushottam Sharma and } \\
\text { Kanak Saxena }\end{array}$ & $\begin{array}{l}\text { Application of fuzzy logic and } \\
\text { genetic algorithm in heart } \\
\text { disease risk level prediction }\end{array}$ & - & $\begin{array}{r}\text { Fuzzy Logic } \\
\text { Controller }\end{array}$ & $\begin{array}{l}\text { Efficient and logical engine with the } \\
\text { capability of replicating human } \\
\text { decisions }\end{array}$ \\
\hline $\begin{array}{l}2017 \\
{[16]}\end{array}$ & $\begin{array}{l}\text { Kanika Pahwa, Ravinder } \\
\text { Kumar }\end{array}$ & $\begin{array}{l}\text { Prediction of Heart Disease } \\
\text { using hybrid Techniques for } \\
\text { selecting features }\end{array}$ & - & $\begin{array}{l}\text { Naive Bayes } \\
(\mathrm{NB}) \text { and } \\
\text { Random- } \\
\text { Forest (RF) }\end{array}$ & $\begin{array}{l}\text { Optimization of the classification problem } \\
\text { by adopting hybrid technique of } \\
\text { attribute selection that helps in } \\
\text { removing irrelevant and redundant } \\
\text { attributes }\end{array}$ \\
\hline $\begin{array}{l}2017 \\
{[43]}\end{array}$ & Kaan Uyar and Ahmet Ilhan & $\begin{array}{l}\text { Diagnosis of heart disease using } \\
\text { genetic algorithm-based } \\
\text { trained recurrent fuzzy neural } \\
\text { networks }\end{array}$ & $\begin{array}{l}\text { Ubuntu and } \\
\text { Java }\end{array}$ & $\begin{array}{l}\text { ANN and } \\
\text { RFNN }\end{array}$ & $\begin{array}{l}\text { Determination and extraction of the } \\
\text { unrevealed information about heart } \\
\text { disease }\end{array}$ \\
\hline $\begin{array}{r}2017 \\
\quad[17]\end{array}$ & $\begin{array}{l}\text { Meenal Saini, Niyati } \\
\text { Baliyan, Vineeta Bassi }\end{array}$ & $\begin{array}{l}\text { Prediction of Heart Disease } \\
\text { Severity with Hybrid Data } \\
\text { Mining }\end{array}$ & - & $\begin{array}{l}\text { Hybrid } \\
\text { Classifier } \\
\text { with } \\
\text { Weighted } \\
\text { Voting }\end{array}$ & $\begin{array}{l}\text { Demonstration of favorable outcomes } \\
\text { with the utilization of hybrid data } \\
\text { mining techniques }\end{array}$ \\
\hline $\begin{array}{r}2017 \\
{[44]}\end{array}$ & $\begin{array}{l}\text { Zeinab, Roohallah } \\
\text { Alizadehsani, Mohamad } \\
\text { Roshanzamir, Hossein } \\
\text { Moosaei, Ali Asghar } \\
\text { Yarifard }\end{array}$ & $\begin{array}{l}\text { Computer aided decision } \\
\text { making for heart disease } \\
\text { detection using hybrid neural } \\
\text { network-Genetic algorithm }\end{array}$ & - & GA and NN & $\begin{array}{l}\text { Affordable and adaptive technique to } \\
\text { enhance accuracy and increase the } \\
\text { execution of NN }\end{array}$ \\
\hline $\begin{array}{l}2017 \\
{[18]}\end{array}$ & $\begin{array}{l}\text { Abhishek Rairikar, Vedant } \\
\text { Kulkarni, Vikas Sabale, } \\
\text { Harshavardhan Kale and } \\
\text { Anuradha Lamgunde }\end{array}$ & $\begin{array}{l}\text { Heart disease prediction using } \\
\text { data mining techniques }\end{array}$ & - & $\begin{array}{l}\text { Genetic } \\
\text { Algorithm, } \\
\text { NB, DT } \\
\text { and K-NN }\end{array}$ & $\begin{array}{l}\text { Consumption of only relevant and } \\
\text { irredundant features to achieve } \\
\text { admissible exactness from the } \\
\text { generalization of FDSS }\end{array}$ \\
\hline
\end{tabular}

Khiarak et al. [35]. The system was user-friendly in the strategy of feature selection as well as training and testing of data set and yielded accuracy of $88.25 \%$. Testing was conducted on 303 patients with 13 clinical parameters of heart disease databases from UCI ML respository and T. S. Rajaei hospital. An intelligent medical heart diagnose system (2019) was designed by L. Ali et al. [24]. Data set was extracted from $\mathrm{CCF}$ which considered 13 input attributes out of 76 attributes: AG, CHOL, CA, CP, FBS, EXANG, RECG, THAL, THALACH, RBS, OP. After extracting noisy and redundant features using Chi-square statistical model, the proposed method used Deep Neural Network (DNN) to avoid underfitting and overfitting of network and achieved $93.33 \%$ accuracy.

A hybrid approach (2020) to predict heart disease was proposed by G. Thippa Reddy et al. [36] considering together adaptive GA with FL. The first step followed the selection of features through rough set theory and the implementation of hybrid AGAFL classifier is made in second step. The membership functions were designed in trapezoidal functions. The system consisted of 13 input variables, namely AG, RBP, GR, CHL, MHR, OP, CA, RECG, FBS, CP, SLOPE, THAL and EXANG. Experimental work was done with data base from CCF, HIC and
UCI ML respository which obtained $90 \%, 91 \%$ and $89 \%$ accuracy, respectively. Preethi Krishnan et al. [25] proposed a novel clinical based and intuitive model (2020) for heart disease detection using fuzzy expert system whose accuracy, specificity and sensitivity were 96.6\%, 96.8\% and $95.6 \%$, respectively, using MIT-BIH heart disease data base in Physionet. Better outcomes were generated to detect PVC beats in electrocardiogram signals [57-63]. Fuzzification was done using Gaussian and triangular membership functions. Explanation of another classical model (2020) was described by Anna Karen et al. [47] using $6 \mathrm{ML}$ classifiers out of which maximum accuracy was achieved by (CHI-PCA) with RF where the data were derived from $\mathrm{CH}$ datasets [54-56] . The paper also revealed clear comparative study other classifiers using CCF, HIC and $\mathrm{CH}$ datasets in Apahe Spark 2.2.0. The prediction model (2020) of hybrid approach using ACO and Hybrid K-NN (HKNN) was designed by Sowmiya et al. [37]. Utilization of feature selection was made by ACO, and then another hybrid classifier was implemented in Netbeans IDE. Experiments were conducted in Netbeans IDE with an accuracy of $99.2 \%$ using data obtained from CCF. Comparison with other classifiers along with their accuracies was presented in this study. Mohammad Ali Hassani 
Table 6 List of research papers from 2018-2021 of FL and Hybrid-based approaches

\begin{tabular}{|c|c|c|c|c|c|}
\hline $\begin{array}{l}\text { Year } \\
\text { and } \\
\text { paper }\end{array}$ & Author & Title & $\begin{array}{l}\text { Application } \\
\text { Software }\end{array}$ & AI approach & Strength \\
\hline $\begin{array}{r}2018 \\
{[45]}\end{array}$ & Ion Iancu & $\begin{array}{l}\text { Heart Disease Diagnosis based on } \\
\text { mediative Fuzzy Logic }\end{array}$ & MATLAB & FL & $\begin{array}{l}\text { Resolvement of contradictory } \\
\text { situations by dealing with } \\
\text { inconsistent data in order to } \\
\text { calculate mediate output }\end{array}$ \\
\hline $\begin{array}{r}2018 \\
{[49]}\end{array}$ & $\begin{array}{l}\text { Hasan Kahtan, Kamal } \\
\text { Z.Zamli, Wan Nor } \\
\text { Ashikin, Wan Ahmed } \\
\text { Fatthi, Azma Abdullah, } \\
\text { Noor Shahaiyusniezam }\end{array}$ & $\begin{array}{l}\text { Heart Disease Diagnosis using } \\
\text { Fuzzy Logic }\end{array}$ & JAVA & FL Controller & $\begin{array}{l}\text { Exhibition of a promising, feasible } \\
\text { and suitable system to assist } \\
\text { peculiar diagnosis process }\end{array}$ \\
\hline $\begin{array}{r}2018 \\
{[19]}\end{array}$ & Vishu Madaan, Anjali Goyal & $\begin{array}{l}\text { X-Cardio: Fuzzy Inference System } \\
\text { to Diagnose Heart disease }\end{array}$ & MATLAB & FL Controller & $\begin{array}{l}\text { Solution to resolve a peculiar } \\
\text { problem of diagnosis by dealing } \\
\text { with incomplete and vague } \\
\text { medical records. Moreover, } \\
\text { presentation of an error-free and } \\
\text { user-friendly interface of toolbox }\end{array}$ \\
\hline $\begin{array}{l}2018 \\
{[20]}\end{array}$ & $\begin{array}{l}\text { Oumaima Terrada, } \\
\text { Bouchaib Cherradi, } \\
\text { Abdelhadi Raihani and } \\
\text { Omar Bouattane }\end{array}$ & $\begin{array}{l}\text { A fuzzy medical diagnostic support } \\
\text { system for cardiovascular } \\
\text { diseases diagnosis using risk } \\
\text { factors }\end{array}$ & MATLAB & $\begin{array}{l}\text { FL Contoller } \\
\text { and DT }\end{array}$ & $\begin{array}{l}\text { Suitable solution based on Fuzzy } \\
\text { Logic and further on DT due to } \\
\text { more count of rules to improve } \\
\text { results }\end{array}$ \\
\hline $\begin{array}{l}2019 \\
{[50]}\end{array}$ & $\begin{array}{l}\text { Prerna Jain and Amandeep } \\
\text { Kaur }\end{array}$ & $\begin{array}{l}\text { A Fuzzy Expert System for } \\
\text { Coronary Artery Disease } \\
\text { Diagnosis }\end{array}$ & MATLAB & FL Controller & $\begin{array}{l}\text { Provision of an easy-to-use } \\
\text { graphical presentation of the } \\
\text { dataset along with working } \\
\text { environment resulting in } \\
\text { constructing predictive analytics }\end{array}$ \\
\hline $\begin{array}{r}2019 \\
{[33]}\end{array}$ & $\begin{array}{l}\text { J. Vijayashree, H. Parveen } \\
\text { Sultana }\end{array}$ & $\begin{array}{l}\text { A machine learning framework for } \\
\text { feature selection in heart disease } \\
\text { Classification using Improved } \\
\text { Particle Swarm Optimization } \\
\text { with S.V.M classifier }\end{array}$ & MATLAB & SVM and PSO & $\begin{array}{l}\text { Requirement of an effective and } \\
\text { powerful system in order to trace } \\
\text { the essential features that } \\
\text { contribute towards the diagnosis } \\
\text { of disease }\end{array}$ \\
\hline $\begin{array}{r}2019 \\
{[34]}\end{array}$ & $\begin{array}{l}\text { Monther Tarawnah, Ossama } \\
\text { Embarak }\end{array}$ & $\begin{array}{l}\text { Hybrid Approach for Heart Disease } \\
\text { Prediction using Data Mining } \\
\text { Techniques }\end{array}$ & - & NB and SVM & $\begin{array}{l}\text { Analysis of hidden patterns, } \\
\text { information and relationships } \\
\text { available in the clinical data of } \\
\text { the patients }\end{array}$ \\
\hline $\begin{array}{l}2019 \\
{[21]}\end{array}$ & $\begin{array}{l}\text { Senthil kumar Mohan, } \\
\text { Chandrasegar Thirumalai, } \\
\text { Gautam Srivastava }\end{array}$ & $\begin{array}{l}\text { Effective Heart Disease Prediction } \\
\text { Using Hybrid Machine Learning } \\
\text { Techniques }\end{array}$ & $\begin{array}{l}\text { R Studio } \\
\text { Rattle }\end{array}$ & HRFLM & $\begin{array}{l}\text { A novel approach with high } \\
\text { discriminative power to develop } \\
\text { and frame a model resulting in the } \\
\text { improvement of medical } \\
\text { awareness and reduction in the } \\
\text { expenditure of the treatment }\end{array}$ \\
\hline $\begin{array}{l}2019 \\
{[22]}\end{array}$ & $\begin{array}{l}\text { Yukti Sharma, Rikku } \\
\text { Veliyambara and Rajshree } \\
\text { Shettar }\end{array}$ & $\begin{array}{l}\text { Hybrid Classifier for Identification } \\
\text { of Heart Disease }\end{array}$ & - & $\begin{array}{l}\text { Decision Tree } \\
\text { (DT) and } \\
\text { K-means } \\
\text { clustering } \\
\text { algorithm }\end{array}$ & $\begin{array}{l}\text { Framework of a model that has } \\
\text { ability to generate high accuracy } \\
\text { by hybridism classifiers rather } \\
\text { than single individual classifier }\end{array}$ \\
\hline $\begin{array}{r}2019 \\
{[23]}\end{array}$ & $\begin{array}{l}\text { Saba Bashir, Zain Sikander } \\
\text { Khan, Farhan Hassan } \\
\text { Khan, Khurram Bashir } \\
\text { and Aitzaz Anjum }\end{array}$ & $\begin{array}{l}\text { Improving Heart Disease Prediction } \\
\text { using Feature Selection } \\
\text { Approaches }\end{array}$ & $\begin{array}{l}\text { Rapidminer } \\
\text { Studio }\end{array}$ & $\begin{array}{l}\text { LR, DT, LR } \\
\text { SVM, RF } \\
\text { and NB }\end{array}$ & $\begin{array}{l}\text { Prerequisite of a system that } \\
\text { eliminates unnecessary and } \\
\text { irrelevant factors present in any } \\
\text { data base of heart patients }\end{array}$ \\
\hline $\begin{array}{r}2019 \\
{[46]}\end{array}$ & $\begin{array}{l}\text { Dr. Padmavathi Kora, Dr. } \\
\text { K Meenakshi, Dr. } \\
\text { K Swaraja, Dr. A Rajani } \\
\text { and Md. Kafiul Islam }\end{array}$ & $\begin{array}{l}\text { New hybrid method for heart } \\
\text { disease diagnosis utilizing } \\
\text { optimization algorithm in feature } \\
\text { selection }\end{array}$ & - & $\begin{array}{l}\text { Imperialist } \\
\text { Competitive } \\
\text { Algorithm } \\
\text { (ICC) and } \\
\text { K-NN }\end{array}$ & $\begin{array}{l}\text { A boosting and compatible approach } \\
\text { with acceptable accuracy by using } \\
\text { efficient and reliable classifier }\end{array}$ \\
\hline
\end{tabular}


Table 6 continued

\begin{tabular}{|c|c|c|c|c|c|}
\hline $\begin{array}{l}\text { Year } \\
\text { and } \\
\text { paper }\end{array}$ & Author & Title & $\begin{array}{l}\text { Application } \\
\text { Software }\end{array}$ & AI approach & Strength \\
\hline $\begin{array}{l}2019 \\
{[35]}\end{array}$ & $\begin{array}{l}\text { Jalil Nourmohammadi-Khiarak, } \\
\text { Mohammad-Reza Feizi- } \\
\text { Derakhshi, Khadijeh Behrouzi, } \\
\text { Samaneh Mazaheri, Yashar } \\
\text { Zamani-Harghalani and } \\
\text { Rohollah Moosavi Tayebi }\end{array}$ & $\begin{array}{l}\text { Detection of Cardiac Arrhythmias } \\
\text { using Fuzzy Logic }\end{array}$ & $\begin{array}{r}\text { MATLAB } \\
\text { R2019b }\end{array}$ & $\begin{array}{l}\text { FL } \\
\text { Controller } \\
\text { and ANN }\end{array}$ & $\begin{array}{l}\text { Automatic prediction with the } \\
\text { application of determination } \\
\text { strategies which are PC based } \\
\text { followed by artificial } \\
\text { intelligence }\end{array}$ \\
\hline $\begin{array}{l}2019 \\
{[24]}\end{array}$ & $\begin{array}{l}\text { Liaqat Ali, Atiqur Rahman, } \\
\text { Aurangzeb Khan, Mingyi } \\
\text { Zhou, Ashir Javeed and Javed } \\
\text { Ali Khan }\end{array}$ & $\begin{array}{l}\text { An Automated Diagnostic System } \\
\text { for Heart Disease Prediction } \\
\text { Based on } \chi \text { Statistical Model } \\
\text { and Optimally Configured Deep } \\
\text { Neural Network }\end{array}$ & Python & $\begin{array}{l}\chi^{2} \text { Statistical } \\
\text { Model and } \\
\text { DNN }\end{array}$ & $\begin{array}{l}\text { Removal of noisy and irrelevant } \\
\text { attributes from feature space } \\
\text { along with automation and } \\
\text { improvement in the accuracy of } \\
\text { disease diagnosis }\end{array}$ \\
\hline $\begin{array}{l}2020 \\
{[36]}\end{array}$ & $\begin{array}{l}\text { G. Thippa Reddy, M. Praveen } \\
\text { Kumar Reddy, Kuruva } \\
\text { Lakshmanna, Dharmendra } \\
\text { Singh Rajput, Rajesh Kaluri } \\
\text { and Gautam Srivastava }\end{array}$ & $\begin{array}{l}\text { Hybrid genetic algorithm and a } \\
\text { fuzzy logic classifier for heart } \\
\text { disease diagnosis }\end{array}$ & $\begin{array}{l}\text { MATLAB } \\
7.12\end{array}$ & $\begin{array}{l}\text { FL } \\
\text { Controller } \\
\text { and GA }\end{array}$ & $\begin{array}{l}\text { Application of t-test to show the } \\
\text { existence of significant } \\
\text { difference between proposed } \\
\text { algorithm and present one in } \\
\text { MATLAB R2014a }\end{array}$ \\
\hline $\begin{array}{l}2020 \\
{[25]}\end{array}$ & $\begin{array}{l}\text { Preethi Krishnan, Viswanathan } \\
\quad \text { Rajagopalan, Bashir I. Morshed }\end{array}$ & $\begin{array}{l}\text { A Novel Severity Index of Heart } \\
\text { Disease from Beat-wise } \\
\text { Analysis of ECG Using Fuzzy } \\
\text { Logic for Smart-Health }\end{array}$ & PhysioNet & $\begin{array}{l}\text { FL } \\
\quad \text { Controller }\end{array}$ & $\begin{array}{l}\text { Real time applicable clinical based } \\
\text { and intuitive model which is } \\
\text { computationally efficient to } \\
\text { generate better outcomes to } \\
\text { detect PVC beats in } \\
\text { electrocardiogram signals }\end{array}$ \\
\hline $\begin{array}{l}2020 \\
{[50]}\end{array}$ & $\begin{array}{l}\text { Anna KarenGarate-Escamila, } \\
\text { Amir Hajjam El } \\
\text { Hassani,Emmanuel Andresb }\end{array}$ & $\begin{array}{l}\text { Classification models for heart } \\
\text { disease prediction using feature } \\
\text { selection and PCA }\end{array}$ & $\begin{array}{l}\text { Apahe park } \\
2.2 .0\end{array}$ & $\begin{array}{r}\text { CHI-PCA } \\
\text { and RF }\end{array}$ & $\begin{array}{l}\text { Application of feature selection } \\
\text { method and dimensionality } \\
\text { reduction technique after } \\
\text { tracing the features of the risk of } \\
\text { heart disease }\end{array}$ \\
\hline $\begin{array}{l}2020 \\
{[37]}\end{array}$ & C. Sowmiya, P. Sumitra & $\begin{array}{l}\text { A Hybrid Approach for Mortality } \\
\text { Prediction for Heart Patients } \\
\text { using ACO-HKNN }\end{array}$ & $\begin{array}{l}\text { Netbeans } \\
\text { IDE }\end{array}$ & $\begin{array}{r}\mathrm{ACO} \text { and } \\
\text { HKNN }\end{array}$ & $\begin{array}{l}\text { Design of an innovative hybrid } \\
\text { approach with various } \\
\text { classifiers by selecting } \\
\text { necessary attributes from the } \\
\text { data set }\end{array}$ \\
\hline $\begin{array}{l}2020 \\
{[51]}\end{array}$ & $\begin{array}{l}\text { Mohammad Ali Hassani, Ran } \\
\text { Tao, Marjan Kamyab, } \\
\text { Mohammad Hadi Mohammadi }\end{array}$ & $\begin{array}{l}\text { An Approach of Predicting Heart } \\
\text { Disease Using a Hybrid Neural } \\
\text { Network and Decision Tree }\end{array}$ & - & DT and NN & $\begin{array}{l}\text { Noteworthy approach that deals } \\
\text { with combination of unique } \\
\text { dataset i.e. CCF and Stalog } \\
\text { heart disease dataset, UCI ML } \\
\text { repository }\end{array}$ \\
\hline $\begin{array}{l}2021 \\
{[38]}\end{array}$ & $\begin{array}{l}\text { L. J. Muhammad, Ebrahem A. } \\
\text { Algehyne }\end{array}$ & $\begin{array}{l}\text { Fuzzy-based expert system for } \\
\text { diagnosis of coronary artery } \\
\text { disease in Nigeria }\end{array}$ & MATLAB & $\begin{array}{l}\text { FL and } \\
\text { Improved } \\
\text { C4.5 } \\
\text { algorithm }\end{array}$ & $\begin{array}{l}\text { Requirement of a affordable, } \\
\text { capable, reliable and relatively } \\
\text { unique technology }\end{array}$ \\
\hline
\end{tabular}

et al. [51] used hybrid ML techniques (NN and DT) to demonstrate a prouctive heart disease detection model (2020) with an accuracy of $98.7 \%$. The study made use of 13 input attributes: AG, GR, CP, RBP, CHOL, FBS, RECG, OP, SLOPE, CA, THAL, THALACH and EXANG. Classification of heart disease was done in Weka software tool using the data of 227 patients obtained from $\mathrm{CCF}$ and StaLog heart disease data set. A new and unique hybrid technique (2021) using Fuzzy Logic along with Improved $\mathrm{C} 4.5$ algorithm was designed and implemented by Muhammad et al. [38]. The system consisted of 11 input variables, namely AG, RBP, glucose, LDL CHOL, HDL CHOL, triglycerides, BCL, BMI, MHR, CP and CHL. Mamdani approach was applied in the fuzzy inference engine of 87 rules, and defuzzification was completed by centroid method. The proposed technique was designed and implemented in the MATLAB tool. Experimental work was done with data base from State Ministry of health, Kano, Nigeria which obtained $94.55 \%$ accuracy. Testing dataset was of 100 patients implemented in MATLAB software. The Table 6 presents the list of research papers from 2018-2021 of FL and Hybrid-based approaches. 
Table 7 Summary of accuracy rate of heart disease detection based on FL and Hybrid-based approaches

\begin{tabular}{|c|c|c|c|}
\hline References & Research methodology & Accuracy & Evaluation parameters \\
\hline$[52]$ & FL & $94 \%$ & - \\
\hline [39] & $\begin{array}{l}\text { Demster-Shafer theory of } \\
\text { evidence and fuzzy sets theory }\end{array}$ & $91.58 \%$ & - \\
\hline [40] & FL & $\begin{array}{l}\text { a) } 62.35 \%(\mathrm{CCF}) \text { b) } 46.9 \% \text { (HIC) c) } 51.3 \% \\
\text { (UHS) }\end{array}$ & $\begin{array}{c}\mathrm{K}=10 \text { fold cross validation }(\mathrm{CCF}, \mathrm{HIC}), \mathrm{K}= \\
8 \text { fold cross validation (UHS) }\end{array}$ \\
\hline$[26]$ & $\mathrm{FL}+\mathrm{GA}$ & - & - \\
\hline$[5]$ & $\mathrm{GA}+\mathrm{NN}$ & $94.17 \%$ & Confusion matrix \\
\hline$[27]$ & $\mathrm{FL}+\mathrm{GA}$ & - & - \\
\hline [6] & $\begin{array}{l}\mathrm{GA}+\text { Association classification } \\
\text { rule mining }\end{array}$ & $95 \%$ & Confusion matrix \\
\hline [41] & $\mathrm{FL}+\mathrm{DT}$ & $93.27 \%$ & Confusion matrix \\
\hline$[53]$ & FL & $92 \%$ & - \\
\hline [7] & $\mathrm{GA}+\mathrm{NN}$ & $92 \%$ & Mean square error (MSQ) \\
\hline$[28]$ & $\mathrm{FL}+\mathrm{DT}$ & 69.22 & - \\
\hline$[42]$ & $\mathrm{LR}+\mathrm{MARS}+\mathrm{RS}+\mathrm{ANN}$ & 83.93 & Type-I/Type-II error \\
\hline$[8]$ & $\mathrm{FL}+\mathrm{DT}$ & $90.94 \%$ & $\mathrm{~K}=10$ fold cross validation \\
\hline [9] & FL & $64.41 \%$ & $\mathrm{~K}=10$ fold cross validation \\
\hline [10] & $\mathrm{NNBP}+\mathrm{GA}$ & Near $100 \%$ & \\
\hline [29] & $\mathrm{NB}+$ Rule based methods & $91.5 \%$ & F-measure \\
\hline$[30]$ & $\mathrm{FL}+\mathrm{K}-\mathrm{NN}$ & $91 \%(\mathrm{k}=1)$ & Confusion matrix \\
\hline [11] & FL & $81.82 \%$ & F-measure \\
\hline [12] & FL & - & - \\
\hline [48] & $\mathrm{FL}+\mathrm{DT}$ & $94.05 \%$ & $\mathrm{~K}=10$ cross validation \\
\hline [13] & $\mathrm{NNFFBP}+\mathrm{PSO}$ & $91.94 \%$ & $\mathrm{~K}=10$ cross validation \\
\hline$[14]$ & $\mathrm{GA}+\mathrm{FL}$ & Near $80 \%$ & Confusion Matrix \\
\hline$[31]$ & FL & - & - \\
\hline$[15]$ & FL & $93.33 \%$ & - \\
\hline$[32]$ & FL & $88.11 \%$ & $\mathrm{~K}=10$ cross validation \\
\hline [16] & $\mathrm{NB}+\mathrm{RF}$ & $84.16 \%$ & $\mathrm{~K}=10$ cross validation, $\mathrm{ROC}$ Curve \\
\hline [43] & ANN + Recurrent NN & $97.78 \%$ & F-measure, Root Mean Square Error (RMSE) \\
\hline [17] & $\begin{array}{l}\text { Hybrid classifier with weighted } \\
\text { voting }\end{array}$ & $82.54 \%$ & \\
\hline$[44]$ & $\mathrm{GA}+\mathrm{NN}$ & $93.85 \%$ & ROC Curve \\
\hline [18] & $\mathrm{GA}+\mathrm{NB}+\mathrm{DT}+\mathrm{K}-\mathrm{NN}$ & - & - \\
\hline$[45]$ & FL & - & - \\
\hline [49] & FL & $98 \%$ & - \\
\hline [19] & FL & $82.65 \%$ & - \\
\hline$[20]$ & FL+DT (C4.5 Algorithm) & $63.24 \%$ & - \\
\hline$[50]$ & FL & $91 \%$ & - \\
\hline [33] & $\mathrm{SVM}+\mathrm{PSO}$ & $88.22 \%$ & ROC Curve \\
\hline$[34]$ & $\begin{array}{l}\mathrm{NB}+\mathrm{SVM}+\mathrm{ANN}+\mathrm{DT} \\
\quad(\mathrm{J} 4.8)+\mathrm{GA}\end{array}$ & $89.2 \%$ & F-measure \\
\hline$[21]$ & RF + Linear Model & $88.7 \%$ & F-measure \\
\hline$[22]$ & $\begin{array}{l}\mathrm{DT}+\mathrm{K}-\text { means clustering } \\
\text { algorithm }\end{array}$ & $62 \%$ & $\mathrm{~K}$-fold cross validation \\
\hline$[23]$ & LR, DT, LR SVM, RF, NB & $\begin{array}{l}\text { a) DT- } 82.22 \% \text { b) LR- } 82.56 \% \text { c) RF- } 84.17 \% \text { d) } \\
\text { NB- } 84.24 \% \text { e)LR SVM-84.85\% }\end{array}$ & $\mathrm{K}=5$ fold cross validation \\
\hline$[46]$ & $\mathrm{FL}+\mathrm{ANN}$ & $99.3 \%$ & ROC Curve \\
\hline
\end{tabular}


Table 7 continued

\begin{tabular}{llll}
\hline References & Research methodology & Accuracy & Evaluation parameters \\
\hline$[35]$ & K-NN + ICA & $88.25 \%$ & Confusion matrix \\
{$[24]$} & K-NN + CHI model & $93.33 \%$ & ROC curve, AUC, MCC \\
{$[36]$} & AGAFL & a) $90 \%(\mathrm{CCF})$ b) $91 \%(\mathrm{HIC})$ c) $89 \%$ (UHS) & K = 10 fold cross validation \\
{$[25]$} & FL & $96.6 \%$ & Confusion matrix \\
{$[47]$} & Chi-square+PCA+RF & a) $98.7 \%(\mathrm{CCF})$ b) $99.0 \%(\mathrm{CCF}, \mathrm{HIC}) \mathrm{c}) 99.4 \%(\mathrm{HIC})$ & F1-score \\
{$[37]$} & HKNN + ACO & $99.2 \%$ & Precision/recall \\
{$[51]$} & DT + NN & $98.7 \%$ & F-meaasure/ROC \\
{$[38]$} & FL+ Improved C4.5 algorithm & $94.55 \%$ & ROC \\
\hline
\end{tabular}

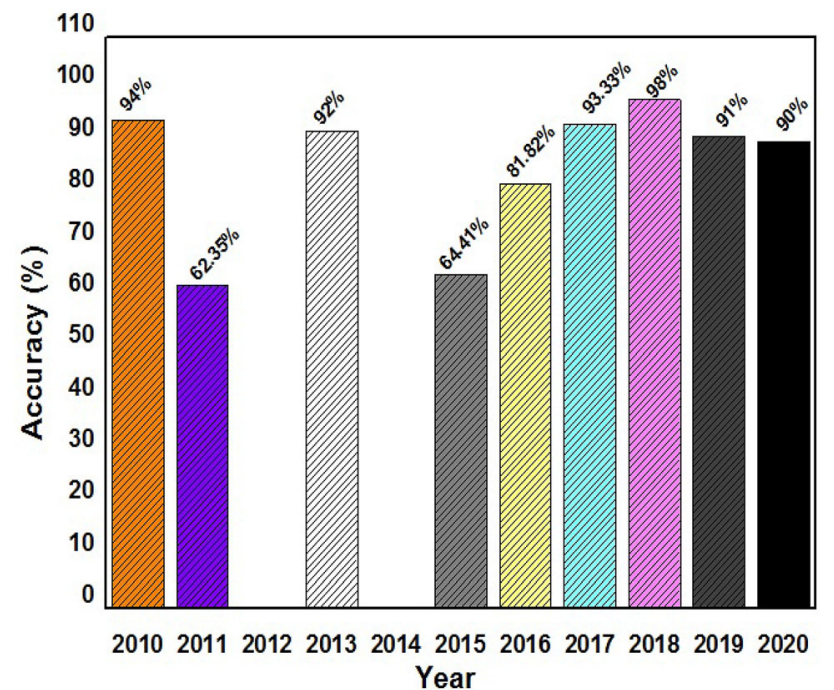

Fig. 5 Year-wise accuracy rate using FL

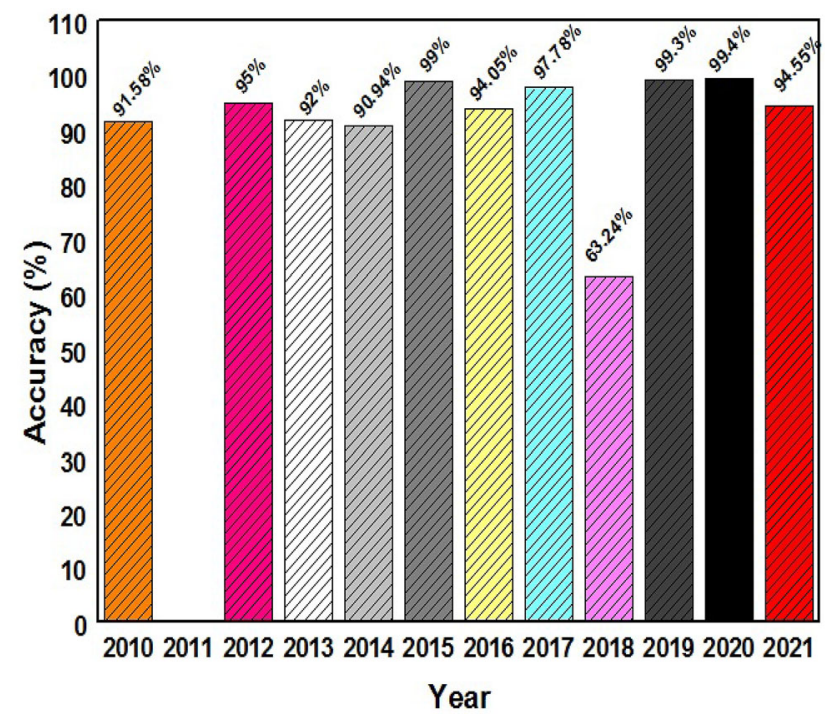

Fig. 6 Year-wise accuracy rate using hybrid system

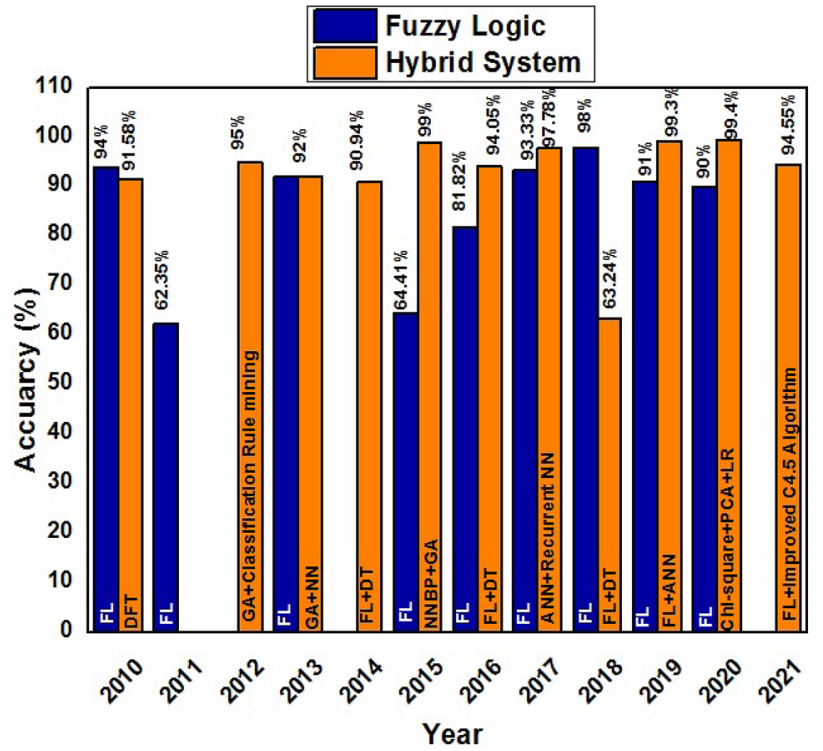

Fig. 7 Year-wise accuracy rate using FL and hybrid system

\section{Comparative Analysis of Accuracies/Techniques}

Accuracy of all respective years for FL and Hybrid System is considered and shown in Table 7 along with evaluation parameters. In the Figs. 5 and 6, higher accuracy in that respective year is shown and further, comparative analysis of both system's accuracies is presented in Fig. 7 along with technique used in that particular paper. All the papers come up with distinct techniques to improve the accuracy in the diagnosis system of heart. The highest accuracy (99.4\%) is achieved by using Fuzzy Logic hybrid with Improved C4.5 algorithm in the current year 2021 [38]. Existence of uncertainty is always there in the detection of any disease. An extensive amount of research has been carried out by various researchers using FL on heart disease detection as FL has enough capability to diagnose heart disease. Therefore, to handle FL is more suitable but the only challenge in FL system is the optimization of rules. If rules are more, complexity of the system increases and if rules are less, system accuracy decreases. Hence, 


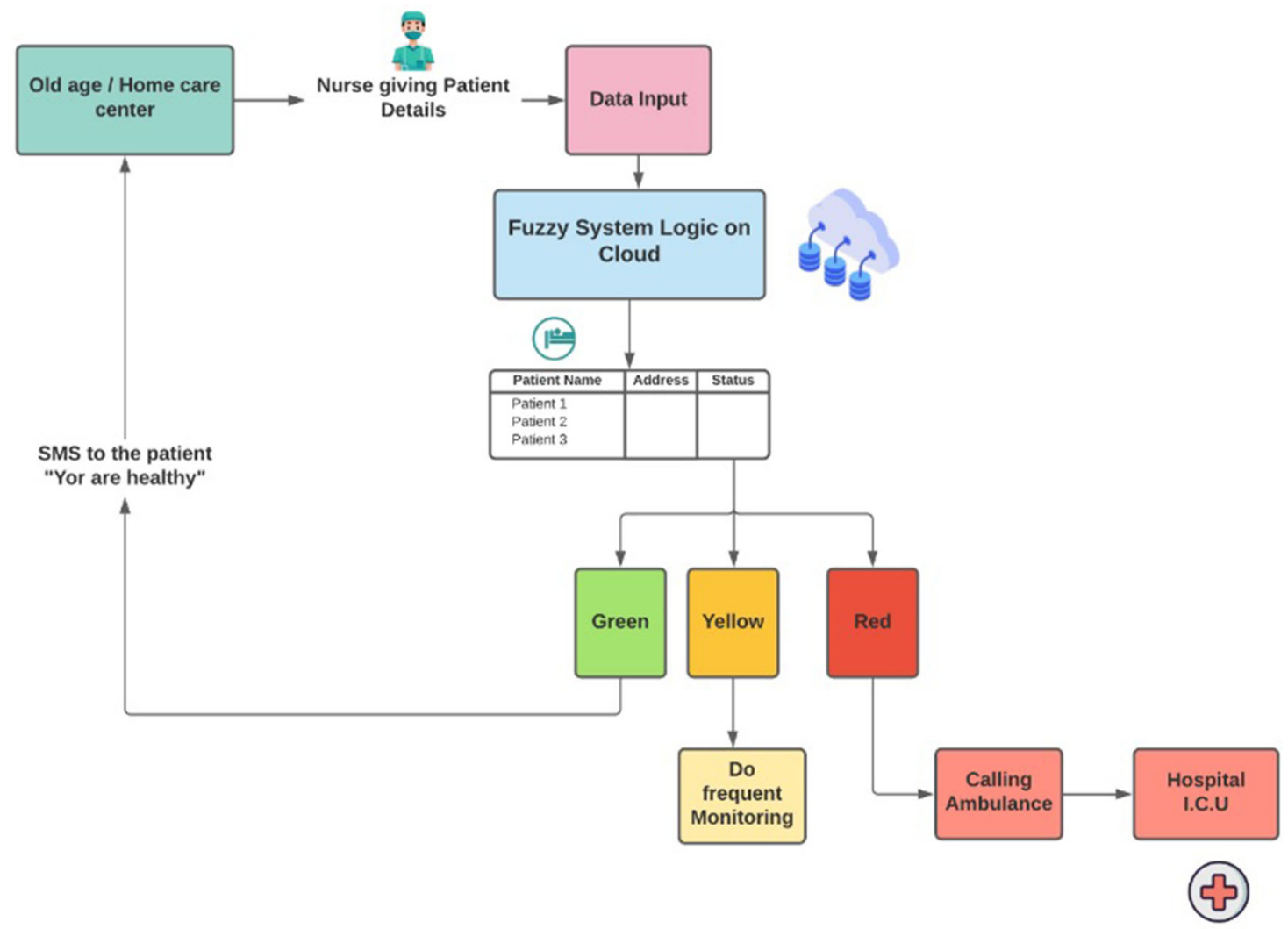

Fig. 8 Future framework of fuzzy logic

selection of optimal rules is a major problem in FL. After that the next and the most used techniques are ANN, GA and DT. ANN is indeed a robust and powerful algorithm still it faces the challenge of the implementation of the automatic detection of the disease due to the complex and complicated structure of the network. Though GA and DT are easy and simple to understand, yet GA is time-consuming algorithm and DT leads to overfitting of the data.

\section{Conclusion}

The paper presents concise information about the diverse work done by various scholars in the field of developing a heart disease detection algorithm and software using soft computing techniques. The paper is the result of in-depth study and analysis of various papers published year-onyear in various renowned journals on this subject. Key finding is that maximum publications are based on FL and FL Hybrid Systems to improve the accuracy using genetic fuzzy logic, fuzzy neural, Adaptive Neuro-Fuzzy, Genetic Neuro-Fuzzy and PSO with FL as FL has enough capability to diagnose the heart disease. Comparison of accuracy of various approaches has been presented graphically, and the best approach is also recommended. The paper also motivates young researchers and scholars to identify the gaps in existing work and take-up the work to create new models and optimize existing models. The efforts should be made to make cost-effective real-life software and tools which can be used by health institutions on a day-to-day basis helping to improve heart disease diagnostics.

\section{Future Model of Fuzzy Logic}

In future, model for direct service of the patients from the old age homes or other home care centers to the Intensive Care Unit (ICU) through ambulance services can be planned. An artificially intelligent system will take the data of clinical parameters from old age homes or other care centers. Fuzzy Logic system will be implemented to get the single output that will reveal distinct stages of patients in terms of healthy, first/second stage of sickness and critical stage. The system will show green color if the status of the person is healthy, and the respective person will be informed via SMS that you are 'Healthy'. Otherwise, if the person is at the first/second stage of sickness, then a SMS 'Do frequent monitoring' will be sent to his/her mobile number. Furthermore, if the patient is at chronic stage of any disease, the system will show red color and the patient 
will be directly brought to the hospital. The Fig. 8 represents the future framework of the fuzzy logic system in any type of disease.

Funding No funding for this paper.

\section{Declarations}

Conflict of Interest The authors declare that they have no conflict of interest.

\section{References}

1. WHO (2019) https://www.who.int/health-topics/cardiovasculardiseases/tab

2. CDC (2019) https://www.cdc.gov/datastatistics/index.html

3. BHF (2020) https://www.bhf.org.uk/informationsupport/heartmatters-magazine/news/behind-the-headlines/coronavirus

4. U. of Oxford, Ai technology can predict heart attacks (2020). https://www.ox.ac.uk/news/2019-09-04-AI-technology-can-predi ct-heart-attacks

5. N.G. Bhuvaneswari, Cardiovasular disease prediction system using genetic algorithm and neural network, in: Proceedings of International Conference on Computing, Communication and Applications (ICCCA), IEEE, pp. 1-5, (2012)

6. M.A. jabbar, P. Chandra, B.L. Deekshatulu, Prediction of risk score for heart disease using associative classification and hybrid feature subset selection, in: Proceedings of International Conference on Intelligent Systems Design and Applications (ISDA), IEEE, pp. 628-634 (2012)

7. S.U. Amin, K. Agarwal, R. Beg, Genetic neural network based data mining in prediction of heart disease using risk factors, in: Proceedings of International Conference on Information and Communication Technologies, IEEE, pp. 1227-1231 (2013)

8. J. Bohacik, C. Kambhampati, D.N. Davis, J.G. Cleland, Use of cumulative information estimations for risk assessment of heart failure patients, in: Proceedings of International Conference on Fuzzy Systems (FUZZ-IEEE), IEEE, pp. 1402-1407 (2014)

9. J. Bohacik, K. Matiasko, M. Benedikovic, I. Nedeljakova, Algorithmic model for risk assessment of heart failure patients, in: Proceedings of International Conference on Intelligent Data Acquisition and Advanced Computing Systems: Technology and Applications (IDAACS), IEEE, pp. 177-181 (2015)

10. A. Dewan, M. Sharma, Prediction of heart disease using a hybrid technique in data mining classification, in: Proceedings of International Conference on Computing for Sustainable Global Development (INDIACom), IEEE, pp. 704-706 (2015)

11. W.M. Baihaqi, N.A. Setiawan, I. Ardiyanto, Rule extraction for fuzzy expert system to diagnose coronary artery disease, in: Proceedings of International Conference on Information Systems and Electrical Engineering (ICITISEE), IEEE, pp. 136-141 (2016)

12. A. Duisenbayeva, L. Atymtayeva, I. Beisembetov, Using fuzzy logic concepts in creating the decision making expert system for cardio vascular diseases (cvd), in: Proceedings of International Conference on Application of Information and Communication Technologies (AICT), IEEE, pp. 1-5 (2016)

13. M.G. Feshki, O.S. Shijani, Improving the heart disease diagnosis by evolutionary algorithm of pso and feed forward neural network, in: Proceedings of International Conference on Artificial Intelligence and Robotics (IRANOPEN), IEEE, pp. 48-53, (2016)
14. A.K. Paul, P.C. Shill, M.R. IslamRabin, M.A.H. Akhand, Genetic algorithm based fuzzy decision support system for the diagnosis of heart disease, in: Proceedings of International Conference on Informatics, Electronics and Vision(ICIEV), IEEE, pp. 145-150 (2016)

15. T. Kasbe, R.S. Pippal, Design of heart disease diagnosis system using fuzzy logic, in: Proceedings of International Conference on Energy, Communication, Data Analytics and Soft Computing (ICECDS), IEEE, pp. 3183-3187 (2017)

16. K. Pahwa, R. Kumar, Prediction of heart disease using hybrid technique for selecting features, in: Proceedings of Uttar Pradesh Section International Conference on Electrical, Computer and Electronics (UPCON), IEEE, pp. 500-504 (2017)

17. M. Saini, N. Baliyan, V. Bassi, Prediction of heart disease severity with hybrid data mining, in: Proceedings of International Conference on Telecommunication and Networks (TEL-NET), IEEE, pp. 1-6 (2017)

18. A. Rairikar, V. Kulkarni, H.K.V. Sabale, A. Lamgunde, Heart disease prediction using data mining techniques, in: Proceedings of International Conference on Intelligent Computing and Control (I2C2), IEEE, pp. 1-8 (2017)

19. V. Madaan, A. Goyal, X-cardio: Fuzzy inference system to diagnose heart diseases, in: Proceedings of International Conference on Advances in Computing, Communication Control and Networking (ICACCCN), IEEE, pp. 1049-1053 (2018)

20. O. Terrada, B. Cherradi, A. Raihani, O. Bouattane, A fuzzy medical diagnostic support system for cardiovascular diseases diagnosis using risk factors, in: Proceedings of International Conference on Electronics, Control, Optimization and Computer Science (ICECOCS), IEEE, pp. 1-6 (2018)

21. S. Mohan, C. Thirumalai, G. Srivastava, Effective heart disease prediction using hybrid machine learning techniques. IEEE Access. 7, 81542-81554 (2019)

22. Y. Sharma, R. Veliyambara, R. shettar, Hybrid classifier for identification of heart disease, in: Proceedings of International Conference on Computational Systems and Information Technology for Sustainable Solution (CSITSS), IEEE, pp. 1-3(2019)

23. S. Bashir, Z.S. Khan, F.H. Khan, K. Bashir, A. Anjum, Improving heart disease prediction using feature selection approaches, in: Proceedings of International Bhurban Conference on Applied Sciences and Technology (IBCAST), IEEE, pp. 619-623 (2019)

24. L. Ali, A. Rahman, A. Khan, M. Zhou, A. Javeed, J.A. Khan, An automated diagnostic system for heart disease prediction based on $\chi^{2}$ statistical model and optimally configured deep neural network. IEEE Access 7, 34938-34945 (2019)

25. P. Krishnan, V. Rajagopalan, B. I. Morshed, A novel severity index of heart disease from beat-wise analysis of ecg using fuzzy logic for smart-health, in: Proceedings of International Conference on Consumer Electronics (ICCE), IEEE, pp. 1-5 (2020)

26. E.P. Ephzibah, A hybrid genetic-fuzzy expert system for effective heart disease diagnosis, in: Proceedings of International Conference on Advances in Computing and Information Technology, Springer, pp. 115-121 (2011)

27. E.P. Ephzibah, V. Sundrapandian, A fuzzy rule based expert system for effective heart disease diagnosis, pp. 196-203 (2012)

28. J.K. Kim, J.S. Lee, D.K. Park, Y. Lim, Y.H. Lee, E.Y. Jung, Adaptive mining prediction model for content recommendation to coronary heart disease patients. Cluster Comput. 17(3), 881-891 (2013)

29. H. Yang, J.M. Garibaldi, A hybrid model for automatic identification of risk factors for heart disease. J. Biomed. inform. 58, 171-182 (2015)

30. V. Krishnaiah, G. Narsimha, N. S. Chandra, Heart disease prediction system using data mining technique by fuzzy k-nn approach, in: Proceedings of Annual Convention of the Computer Society of India (CSI), Springer, pp. 371-384 (2015) 
31. A.M. Alqudah, Fuzzy expert system for coronary heart disease diagnosis in Jordan. Health Technol. 7(2), 215-222 (2017)

32. P. Sharma, K. Saxena, Application of fuzzy logic and genetic algorithm in heart disease risk level prediction. Int. J. Syst. Assur. Eng. Manag. 8(2), 1109-1125 (2017)

33. J. Vijayashree, H.P. Sultana, A machine learning framework for feature selection in heart disease classification using improved particle swarm optimization with support vector machine classifier. Program. Comput. Softw. 44(6), 388-397 (2018)

34. M. Tarawneh, O. Embarak, Hybrid approach for heart disease prediction using data mining techniques. Adv. Internet Data Web Technol. 29, 447-454 (2019)

35. J. Nourmohammadi-Khiarak, M.R. Feizi-Derakhshi, K. Behrouzi, S. Mazaheri, Y. Zamani-Harghalani, R.M. Tayebi, New hybrid method for heart disease diagnosis utilizing optimization algorithm in feature selection. Health and Technology, pp. 1-12 (2019)

36. G. Reddy, M.P.K. Reddy, K. Lakshmanna, D.S. Rajput, R. Kaluri, G. Srivastava, Hybrid genetic algorithm and a fuzzy logic classifier for heart disease diagnosis. Evol. Intell. 13, 185-196 (2020)

37. C. Sowmiya, P. Sumitra, A hybrid approach for mortality prediction for heart patients using ACO-HKNN. J. Ambient Intell. Hum. Comput., pp. 1-8 (2020)

38. L.J. Muhammad, E.A. Algehyne, Fuzzy based expert system for diagnosis of coronary artery disease in Nigeria. Health Technol. 11(2), 1-11 (2021)

39. V. Khatibi, G.A. Montazerac, A fuzzy-evidential hybrid inference engine for coronary heart disease risk assessment. Expert Syst. Appl. 37(12), 8536-8542 (2010)

40. P.K. Anooj, Clinical decision support system: risk level predication of heart disease using weighted fuzzy rules. J. King Saud Univ. Comput. Inf. Sci. 24(1), 27-40 (2011)

41. S. Muthukaruppan, M.J. Er, A hybrid particle swarm optimization based fuzzy expert system for the diagnosis of coronary artery disease. Expert Syst. Appl. 39(14), 11657-11665 (2012)

42. Y.E. Shaoa, C. Houa, C. Chiu, Hybrid intelligent modelling schemes for heart disease classification. Appl. Soft Comput. 14, 47-52 (2014)
43. K. Uyar, A. Ilhan, Diagnosis of heart disease using genetic algorithm based trained recurrent fuzzy neural networks. Proc. Comput. Sci. 120, 588-593 (2017)

44. Z. Arabasadi, R. Alizadehsani, M. Roshanzamir, H. Moosaei, A.A. Yarifard, Computer aided decision making for heart disease detection using hybrid neural network-genetic algorithm. Comput. Methods Programs Biomed. 141, 19-26 (2017)

45. I. Iancu, Heart disease diagnosis based on mediative fuzzy logic. Artif. Intell. Med. 89, 51-60 (2018)

46. P. Kora, K. Meenakshi, K. Swaraja, A. Rajani, M. Kafiul, M.K. Islam, Detection of cardiac arrhythmias using fuzzy logic. Inform. Med. Unlocked 17, 1-7 (2019)

47. A.K. Garate-Escamilla, A.H.E. Hassani, E. Andres, Classification models for heart disease prediction using feature selection and PCA. Inform. Med. Unlocked 19, 1-11 (2020)

48. S. Mokeddem, B. Atmani, Assessment of clinical decision support systems for predicting coronary heart disease. Int. J. Oper. Res. Inf. Syst. (IJORIS) 7(3), 57-73 (2016)

49. H. Kahtan, K. Z. Zamli, W. N. Ashikin, W. A. Fatthi, A. Abdullah, N. Shahaiyusniezam, Heart disease diagnosis using fuzzy logic, in: Proceedings of International Conference on Software and Computer Applications, IEEE, pp. 297-301 (2018)

50. P. Jain, A. Kaur, A fuzzy expert system for coronary artery disease diagnosis, in: Proceedings of International Conference on Advanced Informatics for Computing Research, IEEE, pp. 1-6 (2019)

51. M.A. Hassani, M.K.R. Tao, M.H. Mohammadi, An approach of predicting heart disease using a hybrid neural network and decision tree, in: Proceedings of International Conference on Big Data and Computing, IEEE, pp. 84-89 (2020)

52. A. Adeli, M. Neshat, A fuzzy expert system for heart disease diagnosis, in: International Multi Conference of Engineers and Computer Scientists, 1, pp. 134-139 (2010)

53. S. Kumar, G. Kaur, Detection of heart diseases using fuzzy logic. Int. J. Eng. Trends Technol. 4, 2694-2699 (2013)

Publisher's Note Springer Nature remains neutral with regard to jurisdictional claims in published maps and institutional affiliations. 